\title{
Volcano-earthquake interaction at Mauna Loa volcano, Hawaii
}

\author{
Thomas R. Walter ${ }^{1,2}$ and Falk Amelung ${ }^{1}$ \\ Received 2 June 2005; revised 25 November 2005; accepted 10 January 2006; published 27 May 2006.
}

[1] The activity at Mauna Loa volcano, Hawaii, is characterized by eruptive fissures that propagate into the Southwest Rift Zone (SWRZ) or into the Northeast Rift Zone (NERZ) and by large earthquakes at the basal decollement fault. In this paper we examine the historic eruption and earthquake catalogues, and we test the hypothesis that the events are interconnected in time and space. Earthquakes in the Kaoiki area occur in sequence with eruptions from the NERZ, and earthquakes in the Kona and Hilea areas occur in sequence with eruptions from the SWRZ. Using three-dimensional numerical models, we demonstrate that elastic stress transfer can explain the observed volcano-earthquake interaction. We examine stress changes due to typical intrusions and earthquakes. We find that intrusions change the Coulomb failure stress along the decollement fault so that NERZ intrusions encourage Kaoiki earthquakes and SWRZ intrusions encourage Kona and Hilea earthquakes. On the other hand, earthquakes decompress the magma chamber and unclamp part of the Mauna Loa rift zone, i.e., Kaoiki earthquakes encourage NERZ intrusions, whereas Kona and Hilea earthquakes encourage SWRZ intrusions. We discuss how changes of the static stress field affect the occurrence of earthquakes as well as the occurrence, location, and volume of dikes and of associated eruptions and also the lava composition and fumarolic activity.

Citation: Walter, T. R., and F. Amelung (2006), Volcano-earthquake interaction at Mauna Loa volcano, Hawaii, J. Geophys. Res., 111, B05204, doi:10.1029/2005JB003861.

\section{Introduction}

[2] Volcanic activity is often temporarily and spatially related to the occurrence of large earthquakes [Hill et al., 2002]. The 1707 Mount Fuji eruption started 49 days after a magnitude 8.4 earthquake [Nakamura, 1975]. The eruption of Santa Maria volcano in Guatemala started few days after a M8.3 earthquake in 1902 [Rockstroh, 1902]. Magmatic intrusions encouraged earthquakes in the Izu Peninsula, Japan [Thatcher and Savage, 1982]. Eruptions of Vesuvius in Italy appear to interact with earthquakes in the southern Apennines [Nostro et al., 1998], and earthquakes and flank movement at Mount Etna are related to the volcanic activity [Walter et al., 2005]. The cataclysmic eruption of Mount Pinatubo in the Philippines followed an M7.7 earthquake in 1990 [Bautista et al., 1996], and the eruption of Karymsky in 1996 occurred 2 days after an M7.1 earthquake [Zobin and Levina, 1998]. The joint analysis of earthquake and volcanic eruption catalogues shows that the observed temporal correlation of earthquake and eruption occurrence is statistically significant [Linde and Sacks, 1998; Marzocchi et al., 2002]. A possible mechanism for this interaction may be the transfer of static

\footnotetext{
${ }^{1}$ Division of Marine Geology and Geophysics, Rosenstiel School of Marine and Atmospheric Sciences, University of Miami, Miami, Florida, USA.

${ }^{2}$ Now at GeoForschungsZentrum Potsdam, Potsdam, Germany.

Copyright 2006 by the American Geophysical Union.

0148-0227/06/2005JB003861\$09.00
}

stress, which has been found to play an important role for earthquake-earthquake interactions [e.g., King et al., 1994; Stein, 1999] and may be equally important for volcanoearthquake interactions [Bautista et al., 1996; Nostro et al., 1998; Troise, 2001]. In this paper we test the stress transfer hypothesis for an ocean island volcano.

[3] Our study area is Mauna Loa volcano in Hawaii, one of the most active volcanoes in the world (Figure 1). Mauna Loa is well suited to study earthquake-volcano interaction because the historic eruptions and earthquakes are very well documented. The co-occurrence of earthquakes and eruptions has been noted by several previous workers, e.g., Lipman et al. [1985], Lockwood et al. [1985], Endo [1985], Tilling et al. [1987], Wyss et al. [1992], Okubo [1995], Bryan and Johnson [1991], and Munson et al. [1995].

[4] This paper is organized as follows. First, we review the historic eruption and earthquake catalogues, identify eruptionearthquake sequences in time, and test the statistical significance of the eruption-earthquake sequences (section 2). We then use numerical models to better understand those temporal sequences. We simulate stress changes due to typical intrusions and earthquakes and discuss implications for the historic eruption-earthquake pairs (section 3). The modeling results provide new insights into earthquake occurrence as well as the location, timing, and size of eruptions and dike intrusions at Mauna Loa.

\section{Volcanic and Seismic Activity at Mauna Loa}

[5] The island of Hawaii is composed of five overlapping basaltic shield volcanoes (Kohala, Mauna Kea, Hualalai, 
(a) Historic lava flows 1790-2004

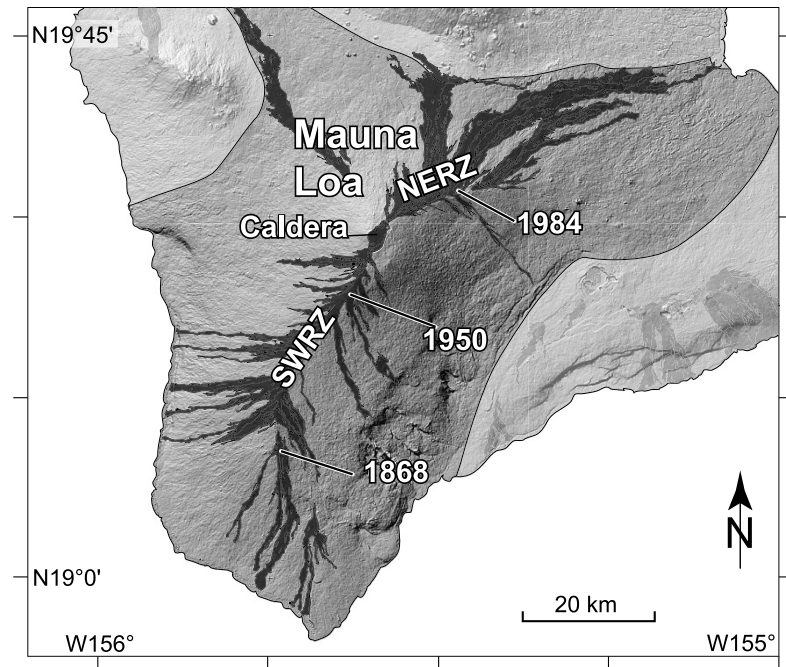

(b) Earthquakes $M>3 \quad 1980-2004$

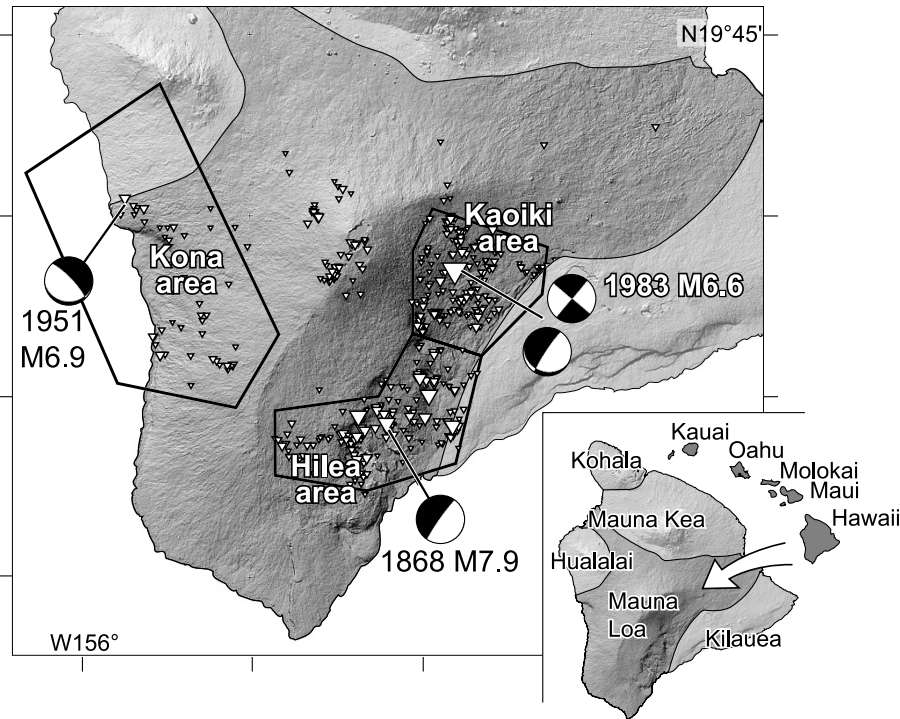

Figure 1. Location and structure of Mauna Loa volcano. Lower inset right shows Hawaiian Islands and Hawaii's Big Island with the five volcanoes Kohala, Mauna Kea, Hualalei, Kilauea, and Mauna Loa (Mauna Loa is shown in darker relief). (a) Historical lava flows on Mauna Loa illustrate the location of the Northeast Rift Zone (NERZ) and the Southwest Rift Zone (SWRZ), conjugating at the summit caldera. Lava flow boundaries are according to Wolfe and Morris [1996]. (b) Earthquake epicenters for events from 1980 to $05 / 2004$, with a magnitude $M>3$ (shown are only if within the area of Mauna Loa). Most earthquakes occur in the areas of Kona and Hilea (low angle thrust-type earthquakes) and in the Kaoiki area (low angle thrust-type earthquakes and also northeast trending strike-slip earthquakes). Also shown are focal mechanisms of three large earthquakes (M6.9 in 1951 at the Kona area, M7.9 in 1868 at the Hilea area, and M6.6 in 1983 at the Kaoiki area, according to Beisser et al. [1994], Liang and Wyss [1991], and Endo [1985]). These three areas (boxes outlined by bold black lines) were previously defined in the Catalog of Hawaiian Earthquakes [Klein and Wright, 2000; Figure 4b] and will hereafter be used for orientation.

Mauna Loa, Kilauea; Figure 1). The Mauna Loa Volcano rises about $8500 \mathrm{~m}$ above the ocean floor $(4169 \mathrm{~m}$ above sea level) and makes up a significant portion of the volume of the island. The geologic structure and evolution of Mauna Loa are complex because of old and new intrusive rift zones, crustal loading and subsidence, lateral spreading, gravitational slumps, and landslides [e.g., Swanson et al., 1976; Lockwood and Lipman, 1987; Dieterich, 1988; Kauahikaua et al., 2000; Borgia et al., 2000]. Mauna Loa grew on the flanks of older edifices to the northwest and to the northeast, a configuration that buttressed the northern volcano sectors and only permitted pronounced flank deformation of the southern sectors [Fiske and Jackson, 1972].

[6] The morphology of Mauna Loa is characterized by the Moku'aweoweo summit caldera and by two opposing elongated ridges that are the Northeast Rift Zone (NERZ) and the Southwest Rift Zone (SWRZ). The rift zones have widened due to repeated dike intrusions and gravity-driven deformation [Nakamura, 1980]. This "spreading" has been accommodated by displacements along a low-angle thrust fault at the base of the edifice, hereafter called the decollement, which coincides with the interface between the oceanic crust and the volcanic edifice [Ando, 1979; Borgia et al., 2000]. Dike intrusions into the rift zones are thought to compress the adjacent flanks of Mauna Loa [Swanson et al., 1976; Decker et al., 1983], causing intermittent flank movement and large earthquakes at the decollement [Wyss, 1986]. Large earthquakes, in turn, may open magma pathways and facilitate dike intrusions and eruptions [Lipman et al., 1985; Cayol et al., 2000].

\subsection{Eruptions and Intrusions}

[7] Mauna Loa had a total of 33 eruptions since 1841 (Table 1a), 17 of which had volumes larger than $100 \times$ $10^{6} \mathrm{~m}^{3}$ and 9 of which had a volume larger than $150 \times$ $10^{6} \mathrm{~m}^{3}$ (Table 1g). Averaged since 1841, Mauna Loa had one large eruption (with a volume $>100 \times 10^{6} \mathrm{~m}^{3}$ ) every 10 years, most of them occurred as flank eruptions at the two rift zones (see eruption record in the work of Lockwood and Lipman [1987]). About 31\% of the historical eruptions occurred along the NERZ, 25\% occurred along the SWRZ, and only $6 \%$ at the radial vents in the northwest [Lockwood and Lipman, 1987; Trusdell, 1995]. The remaining 38\% of the historical eruptions occurred at the summit region (>3960 m elevation) [Lockwood and Lipman, 1987; Barnard, 1995].

[8] Eruptions at Mauna Loa follow a characteristic sequence [Decker et al., 1983]. Prior to an eruption the shallow seismicity increases and doming occurs. Typically, an eruption initiates inside or near the summit caldera, from where eruptive fissures propagate laterally into the NERZ or 
Table 1. Earthquake and Eruption Catalogue of Mauna Loa Used for This Study (Columns a-h), and Co-occurrences (Columns $i-n){ }^{a}$

\begin{tabular}{|c|c|c|c|c|c|c|c|c|c|c|c|c|c|}
\hline (a) & (b) $\mathrm{Y}$ & (c) $\mathrm{M}$ & (d) D & (e) Area & (f) Location & (g) $\mathrm{V}$ or $\mathrm{M}$ & (h) Used Here & (i) & (j) & $(\mathrm{k})$ & (1) & $(\mathrm{m})$ & $(\mathrm{n})$ \\
\hline eq & 1841 & 3 & 11 & Kona & nd & $M=6.1$ & eq & $\mathrm{X}$ & $\mathrm{X}$ & $\mathrm{X}$ & $\mathrm{X}$ & & \\
\hline er & 1843 & 1 & 10 & NERZ & $+17 \mathrm{~km}(2990 \mathrm{~m})$ & $V=202$ & $\mathrm{er}^{+}$ & & & & & & \\
\hline er & 1849 & 5 & 15 & Summit & $\pm 5 \mathrm{~km}(3960 \mathrm{~m})$ & $\mathrm{V}=25$ & er & $\mathrm{X}$ & $\mathrm{X}$ & & & & \\
\hline eq & 1849 & 7 & 15 & Hilea & nd & $\mathrm{M}=6.2$ & eq & & & & & & \\
\hline er & 1851 & 8 & 8 & Summit & $\pm 5 \mathrm{~km}(3960 \mathrm{~m})$ & $\mathrm{V}=35$ & er & & & & & & \\
\hline er & 1852 & 2 & 17 & NERZ & $+21 \mathrm{~km}(2560 \mathrm{~m})$ & $\mathrm{V}=182$ & $\mathrm{er}^{+}$ & $\mathrm{X}$ & $\mathrm{X}$ & $\mathrm{X}$ & $\mathrm{X}$ & $\mathrm{X}$ & \\
\hline eq & 1852 & 3 & 31 & Kaoiki & nd & $\mathrm{M}=6.2$ & eq & & & & & & \\
\hline er & 1855 & 8 & 11 & NERZ & $+14 \mathrm{~km}(3200 \mathrm{~m})$ & $\mathrm{V}=280$ & $\mathrm{er}^{+}$ & & & & & & \\
\hline er & 1859 & 1 & 23 & NERZ & $+18 \mathrm{~km}(2800 \mathrm{~m})$ & $\mathrm{V}=383$ & $\mathrm{er}^{+}$ & & & & & & \\
\hline er & 1865 & 12 & 30 & Summit & $\pm 5 \mathrm{~km}(3960 \mathrm{~m})$ & $\mathrm{V}=50$ & er & & & & & & \\
\hline er & 1868 & 3 & 27 & SWRZ & $-45 \mathrm{~km}(1010 \mathrm{~m})$ & $\mathrm{V}=123$ & $\mathrm{er}^{+}$ & $\mathrm{X}$ & $\mathrm{X}$ & $\mathrm{X}$ & $\mathrm{X}$ & & $\mathrm{X}$ \\
\hline eq & 1868 & 3 & 28 & Hilea & $10 \mathrm{~km} ?$ & $\mathrm{M}=7.0$ & eq & & & & & & \\
\hline eq & 1868 & 3 & 29 & Hilea & nd & $\mathrm{M}=6.1$ & & & & & & & \\
\hline eq & 1868 & 3 & 30 & Hilea & nd & $\mathrm{M}=6.1$ & & & & & & & \\
\hline eq & 1868 & 4 & 1 & Hilea & nd & $M=6.1$ & & & & & & & \\
\hline eq & 1868 & 4 & 2 & Hilea & $10 \mathrm{~km} ?$ & $\mathrm{M}=7.9$ & & & & & & & \\
\hline eq & 1868 & 4 & 3 & Hilea & nd & $\mathrm{M}=6.2$ & & & & & & & \\
\hline er & 1871 & 8 & 10 & Summit & $\pm 5 \mathrm{~km}(3960 \mathrm{~m})$ & $\mathrm{V}=20$ & er & & & & & & \\
\hline er & $1872-76$ & 8 & 9 & Summit & $\pm 5 \mathrm{~km}(3960 \mathrm{~m})$ & $\mathrm{V}=630$ & $\mathrm{er}^{+}$ & & & & & & \\
\hline er & 1877 & 2 & 14 & NW-flank & $(-55 \mathrm{~m} \mathrm{bsl})$ & $\mathrm{V}=8$ & er & & & & & & \\
\hline er & 1879 & 3 & 9 & Summit & $\pm 5 \mathrm{~km}(3960 \mathrm{~m})$ & $\mathrm{V}=1$ & er & & & & & & \\
\hline er & 1880 & 5 & 1 & Summit & $\pm 5 \mathrm{~km}(3960 \mathrm{~m})$ & $\mathrm{V}=10$ & er & $\mathrm{X}$ & & & & & \\
\hline eq & 1880 & 9 & 23 & Kaoiki & nd & $M=6.6$ & eq & $\mathrm{X}$ & $\mathrm{X}$ & $\mathrm{X}$ & $\mathrm{X}$ & $\mathrm{X}$ & \\
\hline er & 1880 & 11 & 5 & NERZ & $+14 \mathrm{~km}(3170 \mathrm{~m})$ & $V=130$ & $\mathrm{er}^{\mathrm{f}}$ & & & & & & \\
\hline er & 1887 & 1 & 16 & SWRZ & $-38 \mathrm{~km}(1740 \mathrm{~m})$ & $\mathrm{V}=128$ & $\mathrm{er}^{+}$ & $\mathrm{X}$ & $\mathrm{X}$ & $\mathrm{X}$ & $\mathrm{X}$ & & $\mathrm{X}$ \\
\hline eq & 1887 & 1 & 18 & Hilea & $10 \mathrm{~km} ?$ & $\mathrm{M}=6.1$ & eq & & & & & & \\
\hline eq & 1887 & 1 & 23 & Hilea & nd & $\mathrm{M}=6.5$ & & & & & & & \\
\hline er & 1892 & 11 & 30 & Summit & $\pm 5 \mathrm{~km}(3960 \mathrm{~m})$ & $\mathrm{V}=12$ & er & & & & & & \\
\hline eq & 1895 & 12 & 8 & Kona & nd & $\mathrm{M}=6.8$ & eq & $\mathrm{X}$ & $\mathrm{X}$ & & & & \\
\hline er & 1896 & 4 & 21 & Summit & $\pm 5 \mathrm{~km}(3960 \mathrm{~m})$ & $\mathrm{V}=25$ & er & & & & & & \\
\hline er & 1899 & 7 & 1 & NERZ & $+13 \mathrm{~km}(3260 \mathrm{~m})$ & $\mathrm{V}=81$ & er & & & & & & \\
\hline er & 1903 & 9 & 1 & Summit & $\pm 5 \mathrm{~km}(3960 \mathrm{~m})$ & $\mathrm{V}=3$ & er & & & & & & \\
\hline er & 1903 & 10 & 6 & Summit & $\pm 5 \mathrm{~km}(3960 \mathrm{~m})$ & $\mathrm{V}=70$ & & & & & & & \\
\hline er & 1907 & 1 & 9 & SWRZ & $-35 \mathrm{~km}(1890 \mathrm{~m})$ & $\mathrm{V}=121$ & $\mathrm{er}^{+}$ & & & & & & \\
\hline er & 1914 & 11 & 25 & Summit & $\pm 5 \mathrm{~km}(3960 \mathrm{~m})$ & $\mathrm{V}=55$ & er & $\mathrm{X}$ & & & & & \\
\hline eq & 1915 & 3 & 28 & Hilea & nd & $M=6.4$ & eq & $\mathrm{X}$ & $\mathrm{X}$ & & & & \\
\hline er & 1916 & 5 & 19 & SWRZ & $-28 \mathrm{~km}(2260 \mathrm{~m})$ & $\mathrm{V}=31$ & er & & & & & & \\
\hline eq & 1918 & 9 & 14 & Hilea & $10 \mathrm{~km} ?$ & $\mathrm{M}=6.0$ & eq & $\mathrm{X}$ & $\mathrm{X}$ & $\mathrm{X}$ & $\mathrm{X}$ & & $\mathrm{X}$ \\
\hline eq & 1918 & 11 & 1 & Hilea & $10 \mathrm{~km} ?$ & $M=6.4$ & & & & & & & \\
\hline er & 1919 & 9 & 26 & SWRZ & $-27 \mathrm{~km}(2350 \mathrm{~m})$ & $\mathrm{V}=183$ & $\mathrm{er}^{+}$ & & & & & & \\
\hline er & 1926 & 4 & 10 & SWRZ & $-27 \mathrm{~km}(2320 \mathrm{~m})$ & $\mathrm{V}=121$ & $\mathrm{er}^{+}$ & & & & & & \\
\hline er & 1933 & 12 & 2 & Summit & $\pm 5 \mathrm{~km}(3960 \mathrm{~m})$ & $\mathrm{V}=100$ & $\mathrm{er}^{+}$ & & & & & & \\
\hline er & 1935 & 11 & 21 & NERZ & $\pm 5 \mathrm{~km}(3690 \mathrm{~m})$ & $\mathrm{V}=87$ & er & & & & & & \\
\hline er & 1940 & 4 & 7 & Summit & $\pm 5 \mathrm{~km}(3960 \mathrm{~m})$ & $\mathrm{V}=110$ & $\mathrm{er}^{+}$ & $\mathrm{X}$ & & & & & \\
\hline eq & 1941 & 9 & 25 & Kaoiki & $11.2 \mathrm{~km}$ & $M=6.0$ & eq & & $\mathrm{X}$ & $\mathrm{X}$ & $\mathrm{X}$ & & \\
\hline eq & 1942 & 2 & 21 & Kaoiki & $8 \mathrm{~km}$ & $\mathrm{M}=6.1$ & & $\mathrm{X}$ & & & & $\mathrm{X}$ & \\
\hline er & 1942 & 4 & 26 & NERZ & $+18 \mathrm{~km}(2800 \mathrm{~m})$ & $V=176$ & $\mathrm{er}^{+}$ & & & & & & \\
\hline er & 1949 & 1 & 6 & Summit & $\pm 5 \mathrm{~km}(3960 \mathrm{~m})$ & $V=116$ & $\mathrm{er}^{+}$ & $\mathrm{X}$ & & & & & \\
\hline eq & 1950 & 5 & 29 & Kona & $9-12 \mathrm{~km}$ & $\mathrm{M}=6.3$ & eq & $\mathrm{X}$ & $\mathrm{X}$ & $\mathrm{X}$ & $\mathrm{X}$ & & \\
\hline er & 1950 & 6 & 1 & SWRZ & $-25 \mathrm{~km}(2440 \mathrm{~m})$ & $V=376$ & $\mathrm{er}^{+}$ & $\mathrm{X}$ & & & & & $\mathrm{X}$ \\
\hline eq & 1951 & 8 & 21 & Kona & $10 \mathrm{~km}$ & $\mathrm{M}=6.9$ & eq & & & & & & \\
\hline eq & 1959 & 5 & 29 & Kona & $8.1-10.2 \mathrm{~km}$ & $\mathrm{M}=6.3$ & eq & & & & & & \\
\hline eq & 1962 & 6 & 27 & Kaoiki & $10.2 \mathrm{~km}$ & $\mathrm{M}=6.1$ & eq & & & & & & \\
\hline er & 1975 & 7 & 5 & NERZ & $\pm 5 \mathrm{~km}(3960 \mathrm{~m})$ & $\mathrm{V}=30$ & er & & & & & & \\
\hline eq & 1983 & 11 & 16 & Kaoiki & $11 \mathrm{~km}$ & $M=6.7$ & eq & $\mathrm{X}$ & $\mathrm{X}$ & $\mathrm{X}$ & $\mathrm{X}$ & $\mathrm{X}$ & \\
\hline er & 1984 & 3 & 25 & NERZ & $+18 \mathrm{~km}(2860 \mathrm{~m})$ & $\mathrm{V}=220$ & $\mathrm{er}^{+}$ & & & & & & \\
\hline 33 er $23 \mathrm{eq}$ & & & & & & & $32 \mathrm{er}, 17 \mathrm{er}^{+}, 15 \mathrm{eq}$ & 17 & 12 & 9 & 9 & 4 & 4 \\
\hline
\end{tabular}

${ }^{a}$ Column a is eruptions (er) and earthquakes (eq). Column b is year, $\mathrm{c}$ is month, $\mathrm{d}$ is day, $\mathrm{e}$ is location, $\mathrm{f}$ is details of location of eruption fissure (the position of the main eruption vent is given by the distance (in kilometers) from the summit caldera, being negative along the SWRZ and positive along the NERZ; brackets give altitudes, in $\mathrm{m}$, of main eruption vents above sea level), nd is not defined. Column $\mathrm{g}$ is eruption volume, $\mathrm{V}$, in $10^{6} \mathrm{~m}^{3}$, or earthquake magnitude, M. Column $\mathrm{h}$ is declustered catalogue used in this study (32 eruptions, 15 earthquakes), where er ${ }^{+}$are eruptions larger $100 \times$ in $^{2} 0^{6} \mathrm{~m}^{3}$ (17 eruptions). The co-occurrence analysis is shown in columns $\mathrm{i}-\mathrm{n}$. Column $\mathrm{i}$ is all pairs (earthquake-eruption pairs and eruption-earthquake pairs), $\mathrm{j}$ is eruption-earthquake sequences, $\mathrm{k}$ is only those sequences that involved eruptions larger $100 \times$ in $10^{6} \mathrm{~m}^{3}, 1$ is sequences that involved large rift zone eruptions only, $\mathrm{m}$ is Koiki earthquake-NERZ eruption sequences, $\mathrm{n}$ is Kona/Hilea earthquake-SWRZ eruption sequences. Historical eruptions are after Lockwood and Lipman [1987], historical earthquakes shallower $20 \mathrm{~km}$ depth (M6 or higher) with known location are after Klein and Wright [2000].

into the SWRZ. Some of the eruptive fissures propagate more than $40 \mathrm{~km}$ into the rift zones.

[9] The fissure eruptions are thought to be associated with a dike intrusion [e.g. Swanson et al., 1976; Lipman, 1995]. Recent dikes generally followed the surface expres- sion of the rift zones [Fiske and Jackson, 1972]. In order to accommodate the opening of the eruptive fissure and its feeder dike, the volcano must expand horizontally perpendicular to the rift zones. The rift zones have dilated a few kilometers since the Holocene [Decker et al., 1983]. The 
intrusive contribution to the total volcano growth is about 25-30\% [Lipman, 1995].

[10] Rift zones are thought to penetrate the entire volcanic edifice [Decker, 1987]. Dike intrusions along the rift zones may occur as shallow eruptive dikes and as deep noneruptive dikes. The dike that fed the most recent eruption in 1984 was inferred to have a length of roughly $18-24 \mathrm{~km}$, extended to a depth of about $5 \mathrm{~km}$, and a thickness of $0.73 \mathrm{~m}$ [Lockwood and Lipman, 1987; Johnson, 1995]. An average shallow dike at Mauna Loa has a length of $20 \mathrm{~km}$, extends from the surface to $3-5 \mathrm{~km}$ depth, and has a thickness of $\sim 0.5 \mathrm{~m}$ [Lipman, 1995]. Deep dike intrusions occur infrequently [Lipman, 1995]. They are a geometrical necessity and may originate at the base of the volcano, similarly as inferred for Kilauea Volcano [cf. Delaney et al., 1998; Wyss et al., 2001; Dieterich et al., 2003]. Shallow dikes intrude at depths between the shallow magma chamber and the free surface, whereas deep dikes intrude between the volcano base (at $8-14 \mathrm{~km}$ ) and the shallow magma chamber [Decker et al., 1983; Hill and Zucca, 1987; Miklius et al., 1995; Johnson, 1995].

[11] The shallow magma chamber is located $3.5-5 \mathrm{~km}$ beneath the summit, as indicated by seismic surveys [Okubo et al., 1997], leveling and GPS measurements [Decker et al., 1983; Miklius et al., 1995], and remote sensing by InSAR [Amelung et al., 2003]. Inflation of the shallow magma chamber typically precedes eruptions [Decker, 1987]. Most of the magma that erupts at the fissures in the caldera or along the upper rift zones passes through this shallow magma chamber [Lockwood and Lipman, 1987]. The shape and size of the magma chamber is not well constrained.

\subsection{Earthquakes}

[12] Since 1841, Mauna Loa Volcano has been the locus of 23 earthquakes with a magnitude larger than M6.0 (Table 1a). Most earthquakes occur in three seismic active areas that are located at the west flank, at the southeast flank, and at the east flank of the volcano (Figure 1b). Following Klein and Wright [2000], we refer to these seismic areas as the Kona area, the Hilea area, and the Kaoiki area, respectively. The largest historic earthquakes are the 1868 M7.9 Hilea earthquake, the 1951 M6.9 Kona earthquake, and the 1983 M6.6 Kaoiki earthquake. The large earthquakes are thought to have occurred along a subhorizontal fault at the base of the edifice (decollement). Beneath Mauna Loa, the decollement is constrained by various geophysical techniques, including seismic refraction experiments [Hill and Zucca, 1987], precise relocation of earthquake hypocenters [e.g., Got and Okubo, 2003; Wolfe et al., 2004], stress tensor inversion from fault plane solutions [e.g., Gillard et al., 1992], and sea-floor mapping [e.g., Morgan et al., 2003]. These studies showed that the decollement is at $8-12 \mathrm{~km}$ under the west flank (Kona coast), at $12-14 \mathrm{~km}$ beneath the summit and rift zones, and at $8-11 \mathrm{~km}$ depth under the eastern flank (Hilea coast and Kaoiki), thus dipping landward toward Mauna Loa at about $5^{\circ}$ (Figure 2).

\subsubsection{Kona Area Earthquakes}

[13] The largest historic earthquake in the Kona area at the western flank of Mauna Loa occurred on 21 August 1951 with a magnitude of 6.9. Kona earthquakes are characterized by a seaward slip direction oriented toward the west-southwest $\left(\mathrm{N} 228^{\circ}-\mathrm{N} 277^{\circ}\right)$ [Gillard et al., 1992].
The direction of slip is thus not exactly perpendicular to the rift but more to the south, probably because of the buttressing effect of Hualalai Volcano [Liang and Wyss, 1991; Gillard et al., 1992; Figure 1b]. The first motion focal mechanisms as well as waveform analysis indicate a nearhorizontal, northwest-southeast striking fault plane, consistent with the decollement model [Gillard et al., 1992; Beisser et al., 1994]. Relocated earthquakes depict the Kona decollement at 8-9 km depths under the coastline and dip eastward to about $14 \mathrm{~km}$ depth under Mauna Loa [Wolfe et al., 2004, Figure 19].

\subsubsection{Hilea Area Earthquakes}

[14] The Hilea area east-southeast of the SWRZ of Mauna Loa was the locus of an M7.9 earthquake in 1868, which was historically the largest and most devastating earthquake in Hawaii [Wyss, 1988]. Significant events also occurred in 1886 (M6.5) and in 1919 (M6.0) [Wyss and Koyanagi, 1992]. Also many recent earthquakes occur in the Hilea area at a depth of roughly $8-12 \mathrm{~km}$ (source: earthquake catalogue of the Advanced National Seismic System). The first motion focal mechanisms indicate seaward decollement faulting toward the southeast (approximately $\mathrm{N} 135^{\circ}$ ), approximately perpendicular to the upper SWRZ [Ando, 1979; Endo, 1985; Liang and Wyss, 1991].

\subsubsection{Kaoiki Area Earthquakes}

[15] The Kaoiki area is located east of the summit of Mauna Loa halfway between the summit calderas of Mauna Loa and Kilauea. Earthquakes in this area are caused by a variety of loading mechanisms such as volcanic activity as well as flank instability [Wyss et al., 1992; Munson et al., 1995]. As a consequence, the fault mechanisms at the Kaoiki area are complex. For example, the 1983 M6.6 event, which was the largest event of the last century, had first-motion focal mechanisms that indicate right-lateral strike-slip along a subvertical fault [Endo, 1985]. The moment tensor solutions as well as the aftershocks, however, suggested decollement slip along a subhorizontal fault [cf. Endo, 1985; Liang and Wyss, 1991; Bryan and Johnson, 1991]. Crustal shear waves and focal mechanisms suggest a heterogeneous crust in the Kaoiki area [Munson et al., 1995; Bryan and Johnson, 1991]. The recent seismicity has components of both strike-slip faulting and decollement faulting. Relative earthquake relocations resolve a subhorizontal decollement fault plane at $\sim 10 \mathrm{~km}$ under the eastern flank of Mauna Loa and, in addition, several northeasttrending subvertical planes at 5-9 $\mathrm{km}$ depth [Got and Okubo, 2003]. The coupling mechanism for strike-slip and decollement faulting is not understood.

\subsection{Historical Eruption-Earthquake Co-occurrence}

[16] A number of previous studies point to the co-occurrence of eruptions and earthquakes at Mauna Loa [e.g., Lockwood et al., 1985; Endo, 1985; Tilling et al., 1987; Wyss et al., 1992; Okubo, 1995; Bryan and Johnson, 1991; Munson et al., 1995]. In the following, we systematically review the historical catalogues. We consider eruptions and earthquakes to be a "sequence" if the temporal separation is less than 2 years (Figure 3). Various eruption-earthquake sequences exist: an eruption followed by an earthquake is an eruption-earthquake pair, an earthquake followed by an eruption is an earthquake-eruption pair; an eruption followed by an earthquake, followed by another eruption is an 


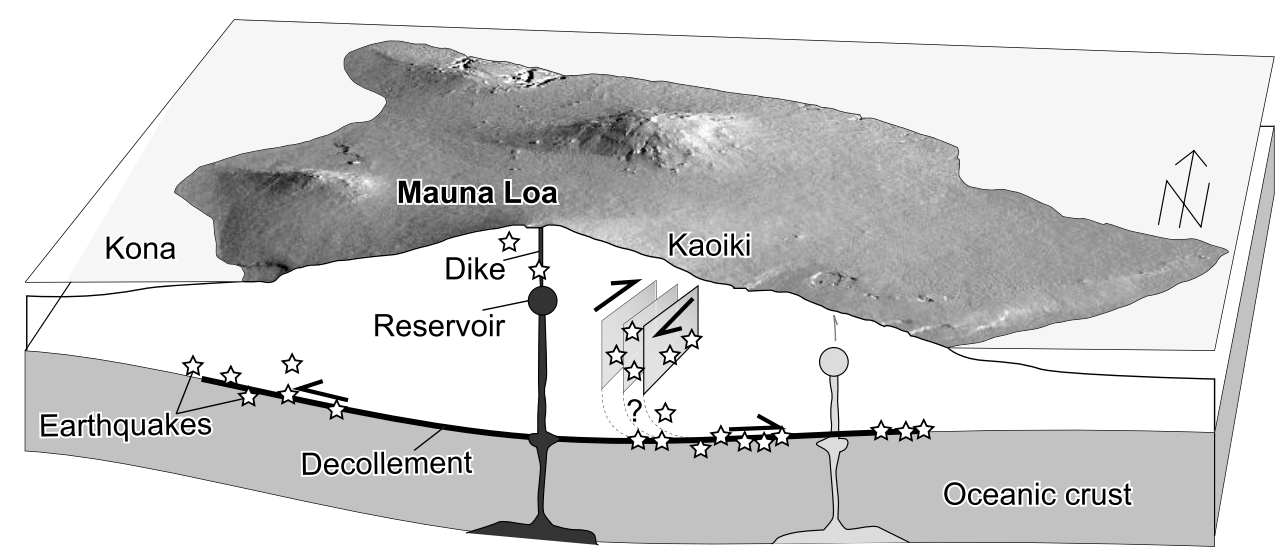

Figure 2. Cross-sectional sketch showing main structures discussed in this paper. Eruptions are controlled by a dike/rift system. Eruptive dikes (shown as vertical lines) pass through a shallow magma chamber (shown here by a sphere, $3-5 \mathrm{~km}$ depth). Earthquakes occur mostly at the basal decollement (the contact between the volcanic edifice and the oceanic crust, $8-12 \mathrm{~km}$ depth), which is slightly bent toward the volcano due to its load. Also focal mechanisms suggest low-dipping thrust-faults. The area between Mauna Loa and Kilauea also experiences strike-slip type earthquakes (at 5-9 km depth). A connection between the vertical Kaoiki strike-slip faults and the decollement beneath is not understood yet (shown here is the listric link).

eruption-earthquake-eruption triplet, and so on. For the purpose of this study we consider only earthquakes with magnitude (M) greater than 6.0 and eruptions with a volume larger than $100 \times 10^{6} \mathrm{~m}^{3}$. The near-continuous eruptive period from 1872 to 1876 is regarded as a single eruption [Lockwood and Lipman, 1987]. Furthermore, we decluster the catalogue and consider eruptions (or earthquakes) that occurred within less than 0.5 years as single events, which leaves us with 17 eruptions and 15 earthquakes (Table $1 \mathrm{~h}$ ). First, we summarize historical eruption-earthquake sequences in time. Second, we analyze eruption-earthquake sequences in time and space, considering only those eruptions along the NERZ or the SWRZ.

\subsubsection{Eruption-Earthquake Sequences}

[17] The historical records provide evidence that the 17 eruptions and 15 earthquakes occurred in 12 eruptionearthquake sequences (Table 1i). During nine of the sequences, eruption volumes exceeded $100 \times 10^{6} \mathrm{~m}^{3}$ (Figure 3 , Table 1j). (1) An M6.1 earthquake on 11 March 1841 was followed by the voluminous NERZ eruption in January 1843 (earthquake-eruption pair). The time lag between the earthquake and the eruption was $\partial \mathrm{T}=670$ days. (2) An eruption at the NERZ on 17 February 1852 was followed by an M6.2 earthquake in the Kaoiki area $(\partial \mathrm{T}=43$ days, eruption-earthquake pair). The subsequent eruption occurred again at the NERZ on 11 August 1855. (3) A period of high eruptive activity initiated on 27 March 1868 with the eruption at the lower SWRZ. Just 1 day later a sequence of at least six Hilea earthquakes larger than M6.0 started, culminating in the M7.9 earthquake on 2 April $1868(\partial \mathrm{T}=$ 1-7 days, eruption-earthquake pair). The subsequent eruptions occurred with time intervals of less than 1 year until 1880. (4) An M6.6 earthquake on 23 September 1880 in the Kaoiki area was followed by an eruption at the NERZ on 5 November $1880(\partial \mathrm{T}=43$ days, earthquake-eruption pair). (5) The 16 January 1887 SWRZ eruption was followed by two Hilea earthquakes, an M6.1 event on 18 January 1887 and an M6.5 event on 23 January $1887(\partial \mathrm{T}=2,5$ days, eruption-earthquake pair). (6) A magnitude M6.4 earthquake in the Hilea area on 1 November 1918 was followed by an eruption at the SWRZ on 26 September $1919(\partial \mathrm{T}=$ 329 days, earthquake-eruption pair). (7) The eruption of 7 April 1940 was followed by two earthquakes with magnitudes M6.0 in the Kaoiki area and with M6.1 at the NERZ on 25 September 1941 and on 21 February 1942 ( $\partial \mathrm{T}=149,536$ days), followed by another NERZ eruption on 26 April $1942(\partial \mathrm{T}=64$ days, eruption-earthquakeeruption triplet). (8) In January 1949 an eruption occurred at the summit region, followed by an M6.3 Kona earthquake on 29 May 1950, which was again followed by an eruption on 1 June 1950 at the SWRZ and another Kona earthquake magnitude M6.9 on 21 August 1951. The 1950 eruption and the 1951 earthquake were the largest eruption and the largest earthquake at Mauna Loa during the 20th century $(\partial \mathrm{T}=508,3,446$ days, eruption-earthquake-eruptionearthquake quadruplet). (9) The M6.6 earthquake of 15 November 1983 was followed by an eruption on 25 March 1984 ( $\partial \mathrm{T}=130$ days, earthquake-eruption pair).

[18] From this historical record we see that four NERZ eruptions occurred in sequence with Kaoiki earthquakes (1852-1852, 1880-1880,1941-1942, and 1983-1984), and four SWRZ eruptions occurred in sequence with Hilea or Kona earthquakes $(1868-1868,1887-1887,1918-$ 1919, and 1950-1951). The locations of the observed eruption-earthquake sequences suggest a relationship between the location of the eruption and the location of the associated earthquake.

\subsubsection{Statistical Significance of Eruption-Earthquake Sequences}

[19] The historical records show that 10 out of 15 earthquakes and 11 out of 17 eruptions occurred as part of an eruption-earthquake sequence (there are nine sequences). Remarkably, nine out of the nine eruption-earthquake sequences involved eruptions that occurred at either the NERZ or the SWRZ (Table 11). Considering the locations, four sequences were associated with eruptions at the NERZ, 


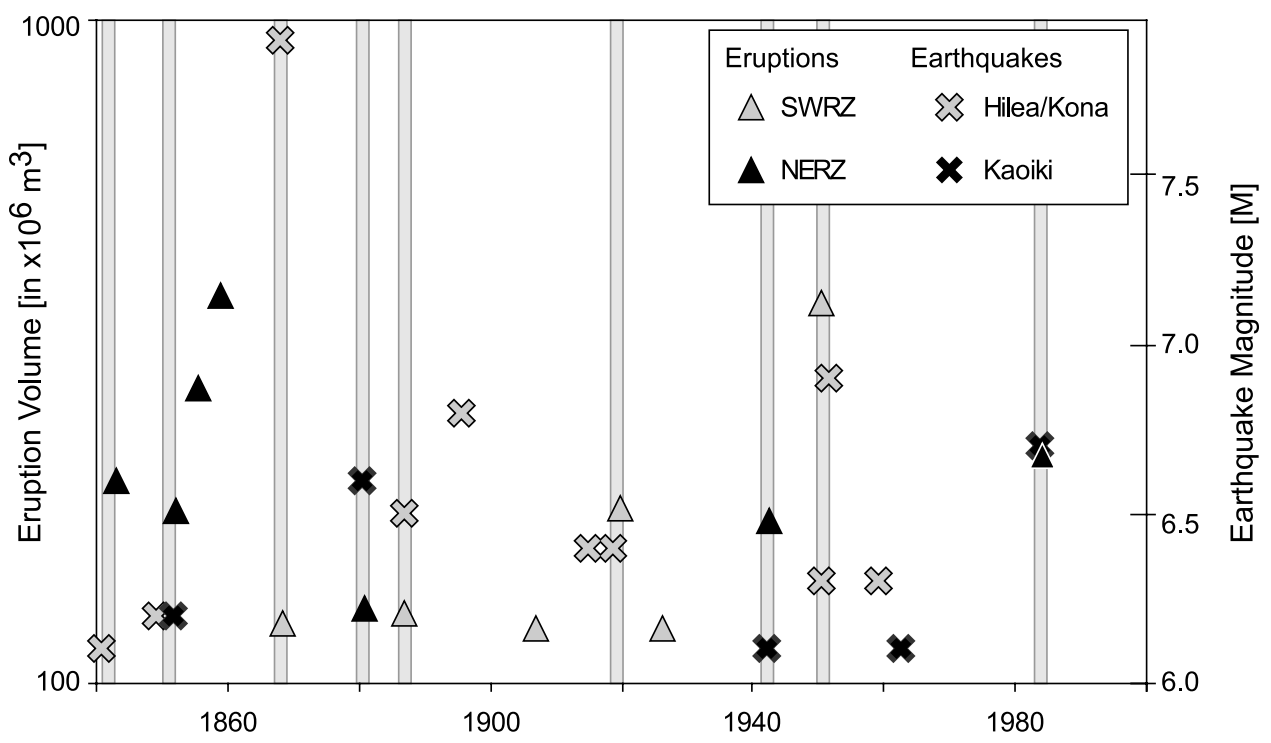

Figure 3. Large eruptions and earthquakes at Mauna Loa co-occur in time and space. The volume of eruptions (shown by triangle symbol) is given on the left ordinate, and the magnitude of earthquakes (shown by cross symbol) is given on the right ordinate. Eruptions at the SWRZ and earthquakes at the Hilea/Kona areas are shown by grey symbols, whereas eruptions at the NERZ and earthquakes at the Kaoiki area are shown by black symbols. Shaded bars highlight co-occurrence of eruptions and earthquakes (nine sequences shown).

and four sequences were associated with eruptions at the NERZ (see Table 1m, 1n). Also the chronological order of earthquakes and eruptions appears to be balanced; in five of the sequences an eruption was followed by an earthquake, and in four of the sequences an earthquake was followed by an eruption.

[20] In order to study the significance of the observed cooccurring earthquakes and eruptions, we use a statistical approach as described by Miklius and Cervelli [2003] to evaluate the temporal correlation of Mauna Loa and Kilauea eruptions. In the Monte Carlo simulation we compute the probability for earthquakes and eruptions to occur as part of eruption-earthquake sequences. We assume that eruptions and earthquakes are independent random processes. Because the historic data covers "only" a limited number of earthquakes and eruptions, we generate a synthetic catalogue based on the activity since 1841 . For this we first fit a normal distribution function to the historic eruption and earthquake data and then generate synthetic catalogues. The synthetic earthquake and eruption catalogue is covering a time period of 20,000 years. For this catalogue we calculate the random probability for an earthquake to occur as part of an eruption-earthquake sequence by counting the number of earthquakes that occurred within less than \pm 2 years from an eruption, and by dividing this number by the total number of earthquakes. In the same way we calculate the random probability for eruptions to occur as part of an eruptionearthquake sequence.

[21] Using this methodology, we find that the random probability of earthquakes and eruptions to occur as part of a sequence is less then $20 \%$ ( 2 out of 10 ). If we consider only rift zone eruptions, we find that $10 \%$ of the SWRZ eruptions occur by random in a sequence with Hilea/Kona earthquakes ( 1 out of 10). Only $5 \%$ of the NERZ eruptions occur by random in a sequence with Kaoiki earthquakes (1 out of 20). These random probabilities are significantly smaller than the observed number of earthquakes and eruptions that occurred as part of sequences. This suggests that the occurrence of earthquakes and eruptions as part of eruption-earthquake sequences is highly significant.

\section{Stress Transfer Models}

[22] In elastic model calculations we examine how eruptions and earthquakes may interact at Mauna Loa volcano. We examine the stress field changes caused by dike intrusions (section 3.2), and the stress field changes caused by earthquakes in the flank of the volcano (section 3.3). Deformation sources are the widening of the rift zones, or slip along different portions of the main faults (decollement or strike-slip). The modeling results are presented as stress change maps in either plan view, cross section, or in the form of depth profiles of strain change. We then use the modeling results to discuss the most important historic earthquake-eruption sequences (section 3.4).

\subsection{Modeling Method}

[23] The stress models are all performed in a threedimensional linear elastic medium, using a modified version of Poly3D, a three-dimensional boundary element code developed by Thomas [1993] and the Stanford Rock Fracture Project. The modeling method is based on the analytical solutions for triangular dislocations in isotropic half and full spaces [Comninou and Dundurs, 1975]. A number of triangular dislocations are combined to model polygonal objects that can have complex three-dimensional shape. Boundary conditions are defined as tractions or displacements at the centre of the input elements. Here, the model inputs are displacements (rift zone opening, fault dislocation). Linear equations are solved to determine the influence 
coefficients for the output boundary elements. In our models, the model outputs are tractions. For more detailed and mathematical descriptions, see Thomas [1993].

[24] We consider the influence of the topography of the volcano by triangulating a digital elevation model (Figure 4) and defining the boundary condition of each of its triangular elements so that the triangular elements simulate a tractionfree crack. This long stress-free "topographic crack" is located in an isotropic full space, simulating a free surface [see, e.g., Martel and Muller, 2000]. We validated this method by simulating a flat topographic crack and a pressure source $[\mathrm{Mogi}, 1958]$, whose results also agree with the analytical half-space solutions of Yang et al. [1988], and then by comparing them with the results of Cayol and Cornet [1998].

[25] As material properties, we assume that the crust is a Poisson solid and assign a Poisson's ratio of $\nu=0.25$. Throughout this study, we use a Young's Modulus E = $70 \mathrm{GPa}$, a value that was determined based on a P-wave travel-time study done in southern Hawaii [Okubo et al., 1997].

\subsection{Stress Changes Due to Magma Intrusion}

[26] To understand how the volcanic activity affects earthquake occurrence at Mauna Loa, we examine stress changes caused by dike intrusions into the rift zone. We consider dike intrusion into the SWRZ as well as dike intrusion into the NERZ and distinguish between eruptive shallow dikes and noneruptive deep dikes. We simulate dikes located (1) between the shallow magma chamber and the free surface (referred to as shallow dikes) and (2) between the decollement and the shallow magma chamber (referred to as deep dikes). The model dikes have a thickness of $0.6 \mathrm{~m}$, consistent with the dike thickness of the 1984 eruptive dike $(0.73 \mathrm{~m})$ [Johnson, 1995] and dike thicknesses measured for the Koolau dike swarm on the Island of Oahu (mean dike thickness $0.53 \mathrm{~m}$ ) [Walker, 1987]. We also consider magma chamber inflation at $5 \mathrm{~km}$ depth below the summit of Mauna Loa. The inflating magma chamber is simulated by a volume increase that approximates a 10 -year inflation period since the last eruption [see also Walter and Amelung, 2004]. Parameters of the modeled intrusions are given in Table 2, and the locations are shown in Figures 4 and 5.

[27] We study how these intrusions change the Coulomb failures stress $(\triangle \mathrm{CFS})$ at the decollement. The decollement is simulated by defining two planes that dip $5^{\circ}$ toward the rift zones of Mauna Loa and join at a depth of $14 \mathrm{~km}$ under the Mauna Loa center (Figures 4 and 5). The western plane simulates the Kona decollement and has a northwest strike $\left(\mathrm{N} 160^{\circ}\right)$ and a southwest slip direction $\left(\mathrm{N} 250^{\circ}\right)$. The eastern plane simulates both the Hilea and the Kaoiki decollement and has a northeast strike $\left(\mathrm{N} 045^{\circ}\right)$ and southeast slip direction $\left(\mathrm{N} 135^{\circ}\right)$. Using this approximation, the decollement beneath the seismic areas of Kona, Hilea, and Kaoiki is located at depths of about 8-12 km (Figure 4) so that the simulated location, strike, dip, and rake of the faults are consistent with the geophysical constraints from Mauna Loa. The Coulomb failure stress depends on changes of the normal stress and shear stress at a given fault plane for a given slip direction [King et al., 1994] and is defined by

$$
\Delta \mathrm{CFS}=\Delta \tau_{\mathrm{r}}+\mu\left(\Delta \sigma_{\mathrm{n}}+\Delta \mathrm{P}\right),
$$

with $\Delta \tau_{\mathrm{r}}$ correlating to the shear stress change on a fault in the expected rake (slip) direction, $\Delta \sigma_{\mathrm{n}}$ the normal stress change, $\Delta \mathrm{P}$ the pore pressure change in the fault zone, and $\mu$ the coefficient of friction. Shear stress is positive in the direction of fault slip. The pore pressure change is defined by $\Delta \mathrm{P}=\mathrm{B} \Delta \sigma_{\mathrm{m}}$, the parameter B is the Skempton's coefficient for which experimental determinations indicate $0.5<$ $\mathrm{B}<0.9$ (we use $\mathrm{B}=0.7$ ), and $\Delta \sigma_{\mathrm{m}}$ is the change in mean stress [Beeler et al., 2000].

[28] A positive change in Coulomb failure stress brings faults closer to failure, i.e., earthquakes are encouraged. A negative change in Coulomb failure stress discourages earthquakes. As we will show now, depending on the location of intrusion, different parts of the active faults experience significant Coulomb stress changes.

\subsubsection{Intrusion Into the NERZ}

[29] We modeled shallow- and deep-dike intrusions into the NERZ, and calculated the $\triangle \mathrm{CFS}$ at the decollement. For shallow-dike intrusions (Figure 5a), $\triangle \mathrm{CFS}$ are slightly negative in the Kona area and positive in the Hilea area. The $\triangle \mathrm{CFS}$ in the Kaoiki area is nonuniform, being partly negative (in the northwest) and partly positive (in the southwest). For deep-dike intrusion (Figure 5b), $\triangle \mathrm{CFS}$ is positive at the Kaoiki zone, in the northern Kona area and in the eastern Hilea area.

\subsubsection{Intrusion Into the SWRZ}

[30] We also modeled dike intrusions into the SWRZ. For the shallow-dike models, the $\triangle \mathrm{CFS}$ increase is largest in the Hilea area, and also in the Kona area (Figure 5c). For deep dike intrusions (Figure 5d) the $\triangle \mathrm{CFS}$ are positive in the Hilea area, but similarly important in the southern parts of the Kona and Kaoiki areas. The magnitude of the stress change is higher than for shallow intrusions. Note that decollement earthquakes in the Kaoiki area mostly occur in the southern part of this area.

\subsubsection{Magma Chamber Inflation}

[31] The $\triangle$ CFS caused by inflation of a shallow magma chamber at $5 \mathrm{~km}$ depth is shown in Figure 5e, indicating that magma chamber inflation encourages decollement faulting (the stress change pattern at the eastern decollement is similar to that in Figure $3 \mathrm{~b}$ of Walter and Amelung [2004]).

[32] In summary, NERZ dike intrusions encourage decollement faulting in the Kaoiki area. The spatial extent of the area of encouraged faulting depends on the depths of the dikes. SWRZ dike intrusions encourage decollement earthquakes in all the three seismic areas, mostly at the Hilea area. For deep dikes, both the spatial extent and the value of Coulomb failure stress increase is more significant. Magma chamber inflation encourages decollement earthquakes, most significantly in the Kaoiki area.

\subsection{Stress Changes Due to Earthquakes}

[33] To understand how flank earthquakes affect the volcano, we now examine Coulomb stress changes caused by the earthquakes. First, we examine changes in normal stress along the rift zones because they determine which sections of the rift zones are unclamped or clamped. Second, we examine strain changes below the summit that may affect possible levels of magma stagnation such as in the shallow magma chamber and at deeper magma bodies. 
(a)

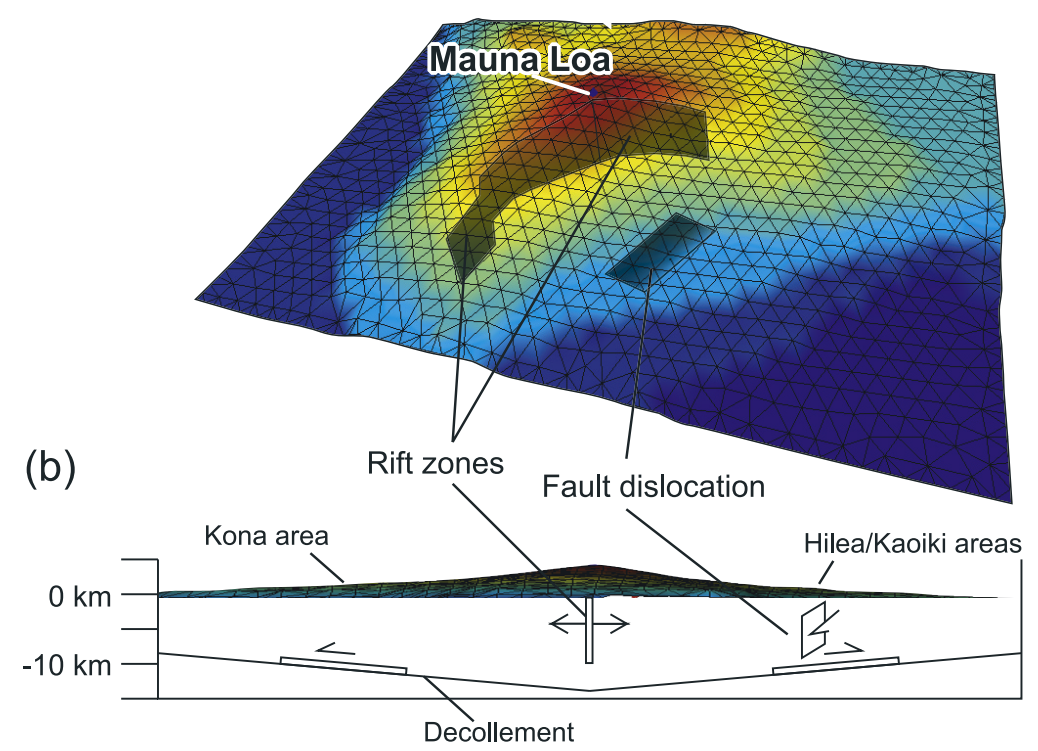

Figure 4. Setup of the Boundary element models. (a) Under a triangulated topographic mesh (1200 elements) sources of dislocation were defined as either crack openings (simulating a dike intrusions), mogi point sources (magma chamber inflation), or fault dislocations (strike slip or thrust component). (b) The topography rises to $+4.2 \mathrm{~km}$; the decollement is situated at $\sim 10 \mathrm{~km}$ depth. Dike intrusions were simulated right under the topographic crest; faults were simulated under the different flanks. See text for details.

[34] We consider decollement earthquakes in the Hilea, Kona, and Kaoiki areas and strike-slip earthquakes in the Kaoiki area. All earthquakes are unit earthquakes at the decollement with $1 \mathrm{~m}$ of uniform displacement on a $10 \mathrm{~km} \times$ $20 \mathrm{~km}$ fault; the long axis is the fault strike. The corresponding moment magnitude of the earthquakes is about M6.2. For the Hilea, Kona, and Kaoiki earthquakes the fault centre is located about $30 \mathrm{~km} \mathrm{SSE}$ of the summit caldera (20 km east of the SWRZ), $34 \mathrm{~km}$ west of the summit caldera (28 km northwest of the SWRZ), and $16 \mathrm{~km}$ ESE of the summit caldera (13 $\mathrm{km}$ south of the NERZ), respectively. For the decollement earthquakes the slip direction of the hanging wall (i.e., of the volcano flank) is roughly at right angles away from the rift zone. The fault parameters are shown in the left insets of Figures 6 and 7 and are given in Table 3 .

\subsubsection{Effects on the Rift Zones}

[35] Figures 6 and 7 show the changes in normal stress $\left(\Delta \mathrm{S}_{\mathrm{n}}\right)$ due to earthquakes in the Hilea, Kona, and Kaoiki area along a cross section that follows the rift zones of the volcano. The point of origin of the cross section $(0 \mathrm{~km})$ corresponds to the center of the caldera (N19.47\% $\left.\mathrm{W} 155.59^{\circ}\right)$. The cross section extends $-65 \mathrm{~km}$ to the southwest into the SWRZ, $+35 \mathrm{~km}$ to the northeast into the NERZ, and to a depth of $16 \mathrm{~km}$ below sea level. We refer to different lateral portions of the rift zones as the upper $(0 \mathrm{~km}$ to $\pm 10 \mathrm{~km})$, central $( \pm 10 \mathrm{~km}$ to $\pm 30 \mathrm{~km})$, and lower rift zones $( \pm>30 \mathrm{~km})$. Positive normal stress changes (tension) indicate unclamping of the rift zone and are identified by the yellow-red color. Negative normal stress changes (compression) indicate clamping of the rift zone and are identified by the color blue.

[36] Hilea earthquakes: The pattern of normal stress change for Hilea decollement earthquakes is shown in Figure 6a. The entire SWRZ is characterized by positive normal stress change (tension) from $-5 \mathrm{~km}$ to $-35 \mathrm{~km}$ south of the caldera (yellow-red = unclamping). The maximum tension occurs in the central SWRZ. Below a depth of $\sim 10 \mathrm{~km}$ (the approximate depth of the model earthquake), the stress change is compressional (blue = clamping). The calculations indicate that Hilea earthquakes facilitate dike

Table 2. Geometry of Typical Intrusions at Mauna Loa Used in the Models ${ }^{\mathrm{a}}$

\begin{tabular}{|c|c|c|c|c|c|}
\hline \multirow[b]{2}{*}{ Mauna Loa Intrusions } & \multirow[b]{2}{*}{ Historic Example } & \multicolumn{2}{|c|}{ Depth, km } & \multirow[b]{2}{*}{ Length, $\mathrm{km}$} & \multirow[b]{2}{*}{ Dislocation, $\mathrm{m}$} \\
\hline & & Min & Max & & \\
\hline Shallow magma chamber & $1985-1995$ & 3.5 & 5 & 2 & $35 \mathrm{M} \mathrm{m}^{3}$ \\
\hline Shallow NERZ intrusion & 1984 & 0 & 5 & 20 & $0.6 \mathrm{~m}$ \\
\hline Deep NERZ intrusion & nd & 5 & 14 & 20 & $0.6 \mathrm{~m}$ \\
\hline Shallow SWRZ intrusion & 1950 & 0 & 5 & 20 & $0.6 \mathrm{~m}$ \\
\hline Deep SWRZ intrusion & nd & 5 & 14 & 20 & $0.6 \mathrm{~m}$ \\
\hline
\end{tabular}

${ }^{\mathrm{a}} \mathrm{Here}$ nd is not defined or imprecise data. The depth is given as below the summit of Mauna Loa, which is at $4.17 \mathrm{~km}$ above sea level (a.s.1.). See text for details. 
Coulomb stress changes at decollement faults due to intrusions
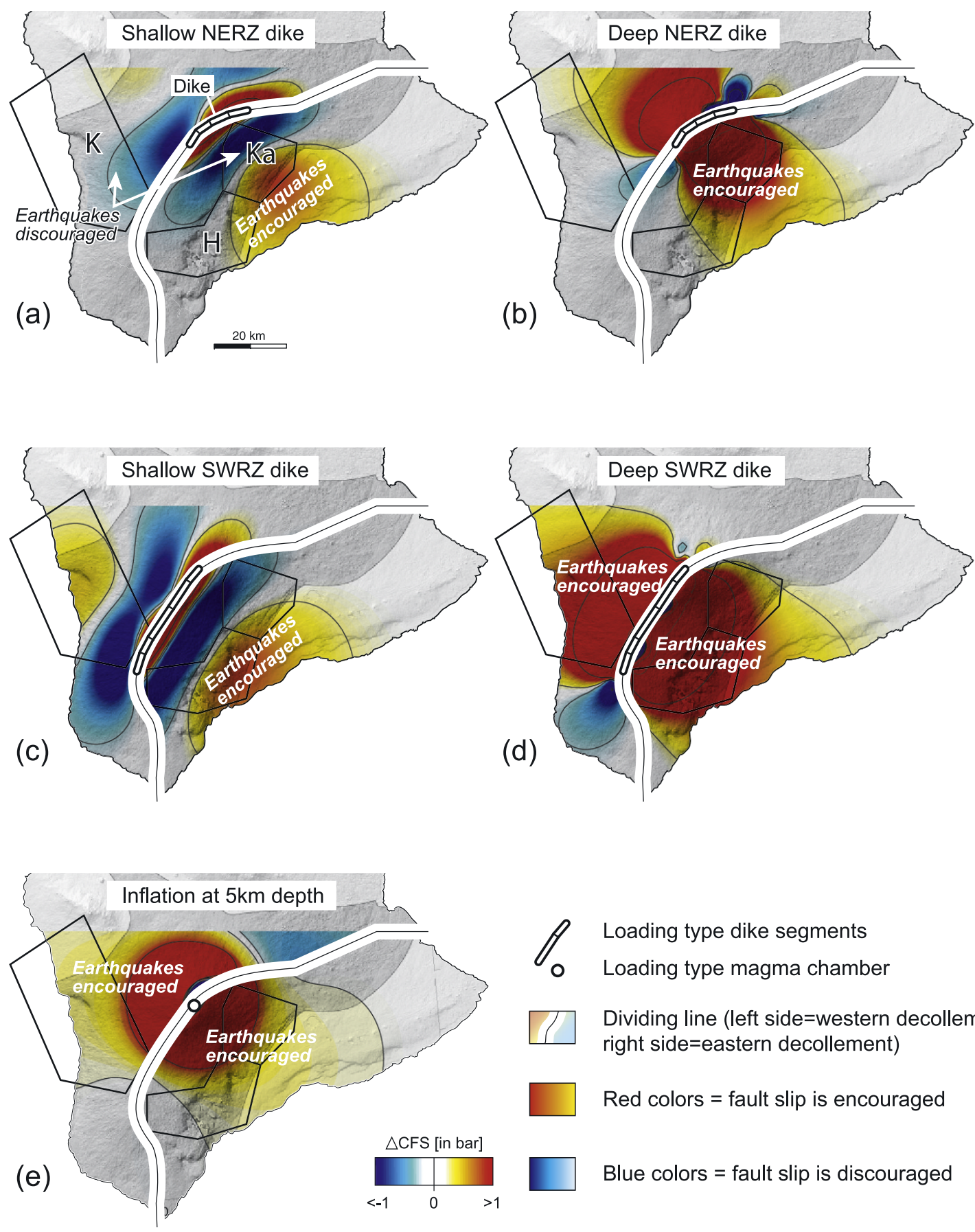

\section{Loading type dike segments Loading type magma chamber}

Dividing line (left side=western decollement right side=eastern decollement)

Red colors $=$ fault slip is encouraged

Blue colors $=$ fault slip is discouraged

Figure 5. Change in Coulomb failure stress at the decollement faults caused by $(a, c)$ shallow dikes and (b, d) deep dikes at the NERZ and SWRZ. The red colors show increase of Coulomb failure stress (earthquakes are encouraged), blue shows decrease of Coulomb stress (earthquakes are discouraged). Each plan view map (in Figures 5a-5d) shows two model calculations: one where the Coulomb stress change for the Kona-type decollement fault is shown to the west and the other where the Coulomb stress change for the Hilea-type and Kaoiki-type decollement faults is shown to the east of the rift zones. Receiver thrust faults strike at the west side $340^{\circ}$ and at the east side $45^{\circ}$, both dip at $5^{\circ}$ toward the volcano $\left(\right.$ rake $90^{\circ}$ ). Isolines at $0.1,1.0,10$ bar, K-Kona area, H-Hilea area, Ka-Koaiki area.

intrusions into the entire SWRZ, mostly into the central part.

[37] Kona earthquakes: For Kona earthquakes, the stress change pattern is similar to the previous case with a shallow area of tensional stress change (red = unclamping, Figure $6 \mathrm{~b}$ ) and a deeper area of compressional stress change (blue $=$ clamping). However, the areas of stress changes are located further up the rift zone than in the previous case, and also 


\section{Normal stress changes at rift zones due to earthquakes}

(a) Hilea-type decollement earthquake
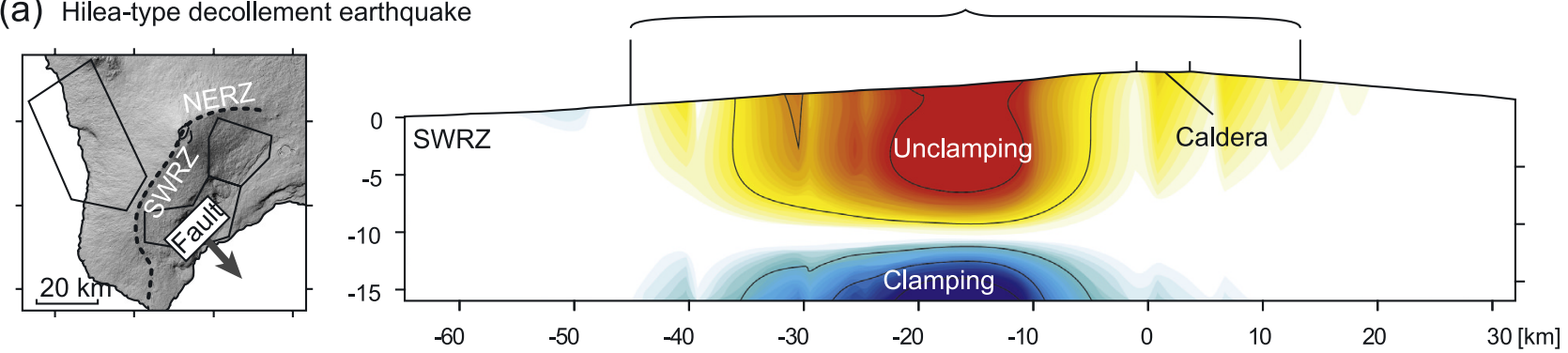

Eruptive fissures 1950

(b) Kona-type decollement earthquake
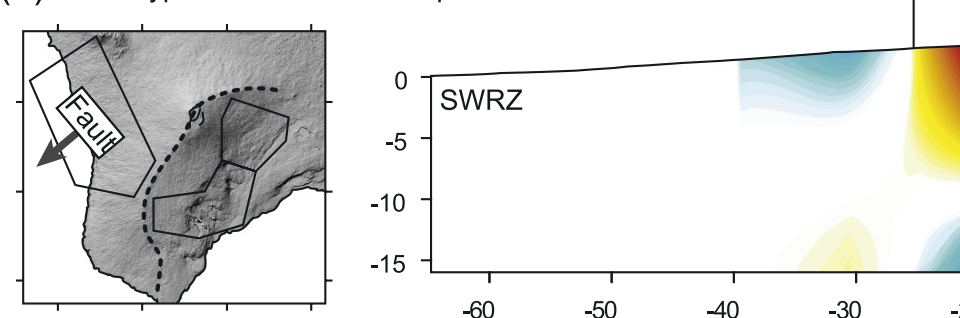

$\overbrace{1}$
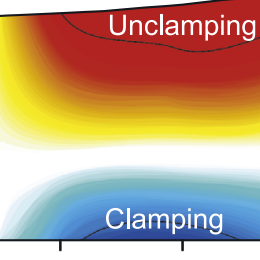

$-10$

(c) Kaoiki-type decollement earthquake
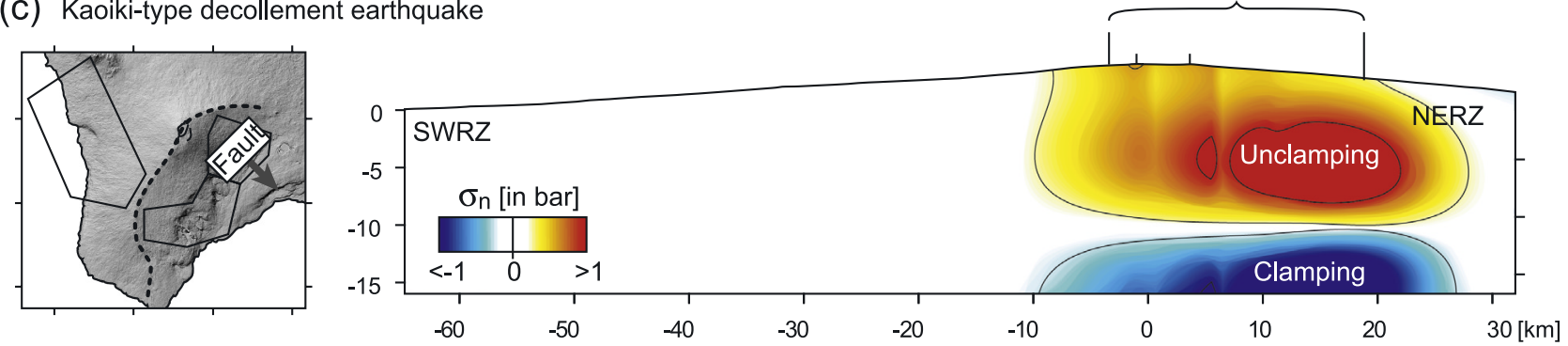

Figure 6. Change in normal stress at profiles along the SWRZ and the NERZ of Mauna Loa caused by M6.2 faulting at the Hilea, Kona, and Kaoiki area decollement faults and also for strike-slip faulting at the Kaoiki area. Insert to the left shows location of unit earthquake and cross-section line (dotted line). In cross sections, positive normal stress changes (red) unclamp the rift zones and encourage dike intrusion, whereas negative normal stress changes (blue) clamp the rift zones, discouraging intrusions. (a) Hilea decollement earthquake at $-10 \mathrm{~km}$ unclamps the central SWRZ. (b) Kona decollement earthquake at $-10 \mathrm{~km}$ unclamps the upper SWRZ. (c) Kaoiki strike-slip earthquake at $-7 \mathrm{~km}$ unclamps the summit area of the rift zones but compresses the lower NERZ.

affect the summit area (between the northern caldera rim at $+2 \mathrm{~km}$ and $-20 \mathrm{~km}$ at the SWRZ). The amplitude of stress changes is somewhat smaller than for Hilea earthquakes because Kona earthquakes are located further from the rift zone. The calculations indicate that Kona earthquakes facilitate dike intrusions into the centre and upper part of the SWRZ.

[38] Kaoiki earthquakes: For Kaoiki decollement earthquakes, the stress change pattern is similar to the previous cases but the main area of stress changes is located in the NERZ (Figure 6c). The location is between $-5 \mathrm{~km}$ and $+25 \mathrm{~km}$. The stress change amplitude is larger than in the previous cases because the earthquake is closer to the rift zones.
[39] Kaoiki earthquakes have components of strike-slip and decollement slip [Endo, 1985; Wyss et al., 1992]. Our models show that Kaoiki strike-slip earthquakes compress the central NERZ (Figure $7 \mathrm{~d}$, between +10 and $+25 \mathrm{~km}$ ) and cause tension in the summit region (between $-10 \mathrm{~km}$ and $+5 \mathrm{~km})$. The areas of tension and compression extend throughout the entire depth of the cross section. A combination of decollement and strike-slip faulting, each corresponding to an M6.2 earthquake, results in tension in the summit area and the upper NERZ (between $-8 \mathrm{~km}$ and $+13 \mathrm{~km}$, Figure 8e), and compression in the central NERZ (between $+15 \mathrm{~km}$ and $+25 \mathrm{~km}$ ). Compression occurs also at a greater depth beneath the summit $(>15 \mathrm{~km})$. In summary, the model calculations indicate that Kaoiki earthquakes unclamp dike paths in the summit area and the upper NERZ 


\section{Normal stress changes at rift zones due to earthquakes}

(d) Kaoiki-type strike-slip earthquake
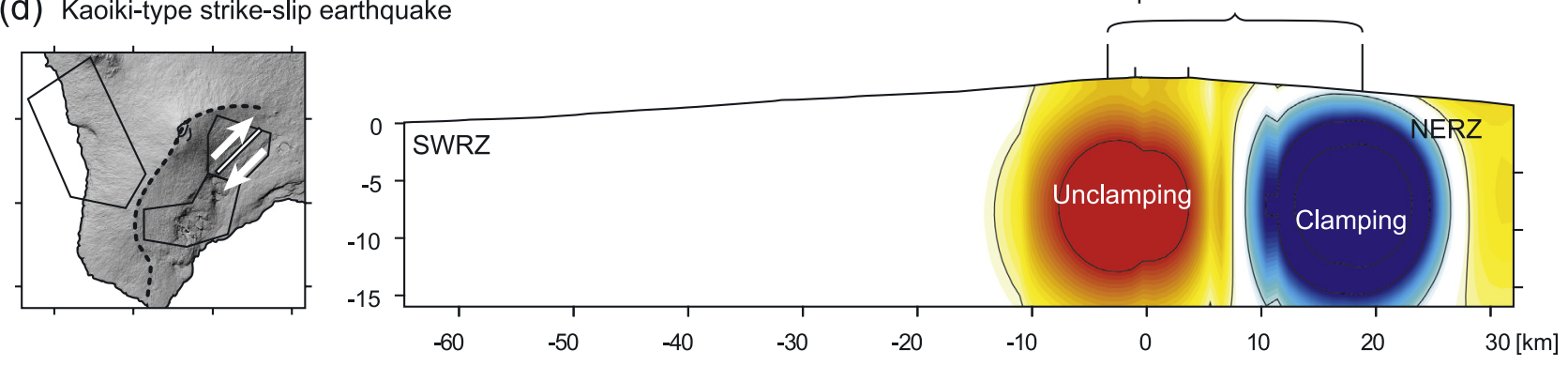

$(e)=(c)+(d)$ Kaoiki-type strike slip + decollement earthquake
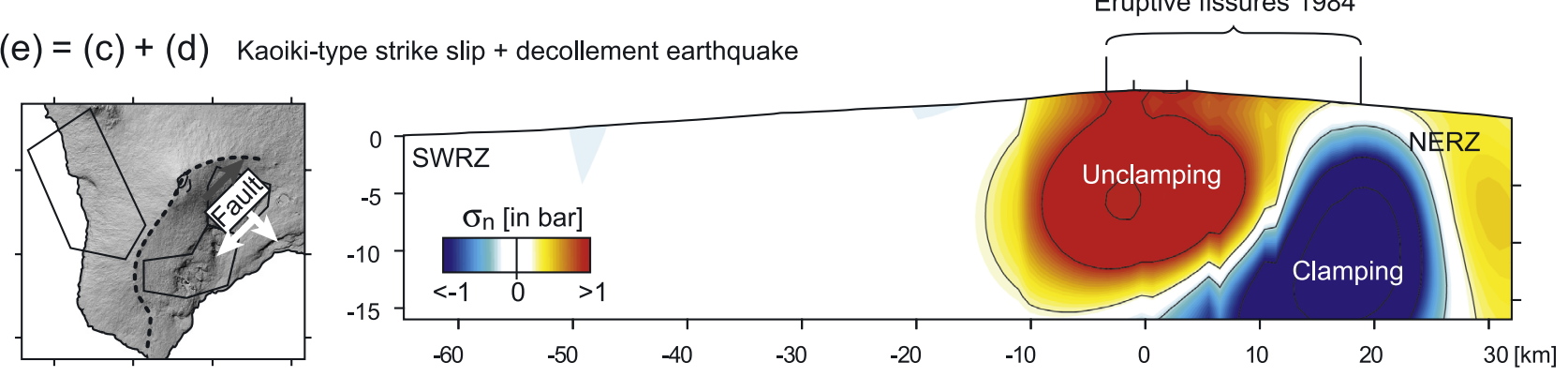

Figure 7. Change in normal stress (continuation of Figure 6). (d) Kaoiki decollement earthquake unclamps the entire NERZ. (e) Coupled strike-slip and decollement earthquakes are likely at Kaoiki, thus the addition of Figure $6 \mathrm{c}$ and Figure $7 \mathrm{~d}$ suggest unclamping of the summit area and of parts of the NERZ. Maximum compression at the NERZ occurs at $20 \mathrm{~km}$ distances from the caldera.

and that they clamp the lower NERZ. The precise location of unclamping/clamping depends on the ratio of decollement versus strike-slip faulting. The tensional area is located further north if decollement faulting dominates and further south in the summit area if strike-slip faulting is the main earthquake mechanism.

\subsubsection{Effects on the Magma Reservoirs}

[40] Here we study how earthquakes may affect the magma chambers. We calculate the elastic dilatational strain $(\varepsilon=$ exx + eyy + ezz $)$ under the center of the summit caldera as a function of depth (Figure 8). Dilatation strain of the rock mass may (1) directly translate into the chamber and affect the magmatic overpressure, (2) promote or hinder magma replenishment into a shallow reservoir and the injection of new hot basaltic magma into a resident chamber which changes the magma overpressure, or (3) alter the volatile pressure and affect the volatile flux from deeper sources. $\varepsilon>0$ is referred to as extension, and $\varepsilon<0$ is referred to as contraction.
[41] Decollement earthquakes (Hilea, Kona, and Kaoiki) cause extension above $\sim 7-10 \mathrm{~km}$ depth and contraction below this level. Extension is largest for Kaoiki earthquakes, and smaller for Hilea or Kona area earthquakes. In general, the profile shows that extension is highest at shallow levels at the upper $5-10 \mathrm{~km}$. The shallow magma plumbing system is subject to extension, whereas deeper levels are subject to contraction. Kaoiki strike-slip earthquakes cause extension at all depths.

\subsection{Implications for Historic Eruption-Earthquake Sequences}

[42] Here we illustrate how the largest historic earthquakes in each of the seismic areas affected volcanism, (1) the 1868 M7.0 to M7.9 earthquakes in the Hilea area, (2) the 1950 M6.3 and the 1951 M6.9 earthquakes in the Kona area, and (3) the 1983 M6.6 earthquake in the Kaoiki area. These earthquakes occurred in a sequence with eruptions at the SWRZ or at the NERZ. The locations of the

Table 3. Parameters of Large Historic Earthquakes at Mauna Loa and of the Unit Earthquakes of This Modeling Study (See Text for Details)

\begin{tabular}{|c|c|c|c|c|c|c|}
\hline \multirow[b]{2}{*}{ Mauna Loa Earthquakes } & \multirow[b]{2}{*}{ Historic Example } & \multirow[b]{2}{*}{ Depth, km } & \multicolumn{4}{|c|}{ Earthquake Models in This Study ${ }^{\mathrm{a}}$} \\
\hline & & & Strike & Dip & Slip & Center of Modeled Fault Plane \\
\hline West flank (Kona) decollement & 1951, M6.9 & $8-12$ & $340^{\circ}$ & $5^{\circ}$ & thrust & N19.28/W155.55 \\
\hline Southeast flank (Hilea) decollement & 1868, M7.9 & $9-11$ & $45^{\circ}$ & $-5^{\circ}$ & thrust & N19.15/W155.32 \\
\hline East flank (Kaoiki) decollement & 1983, M6.6 & $10-11$ & $45^{\circ}$ & $-5^{\circ}$ & thrust & N19.26/W155.26 \\
\hline East flank (Kaoiki) strike-slip & 1983, M6.6 & $5-9$ & $40^{\circ}$ & $90^{\circ}$ & strike-slip & N19.26/W155.26 \\
\hline
\end{tabular}

${ }^{\mathrm{a}}$ Fault plane parameters are based on the work by Endo [1985], Bryan and Johnson [1991], Gillard et al. [1992], Beisser et al. [1994], Jackson et al. [1992], and Got and Okubo [2003]. 


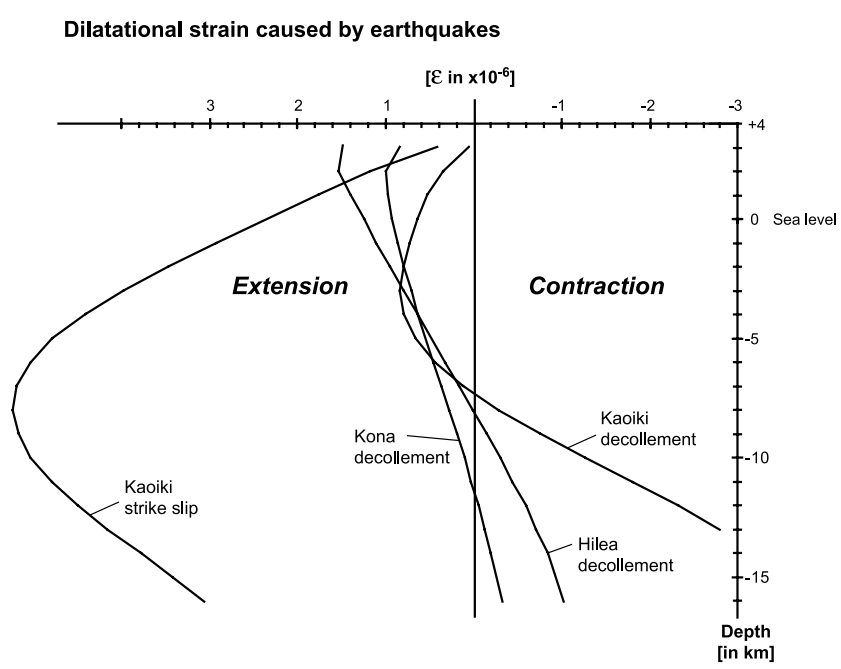

Figure 8. Dilatational strain $\varepsilon$ along a vertical profile under the summit of Mauna Loa, caused by decollement faulting at the Kona, Hilea, and Kaoiki areas and by strikeslip faulting at the Kaoiki area. Note that in general the shallow magma reservoir is subject to coseismic extension.

eruptive fissures are shown in Figures 6 and 7 (as brackets above the cross section).

\subsubsection{Effects of Hilea Earthquakes: Disruption of the Magma Plumbing System by the Great 1868 Earthquake}

[43] The largest historic earthquake on Hawaii occurred in April 1868 in the southeastern area of Mauna Loa near Hilea. It was the main event of a sequence that started with an eruption at the summit and SWRZ on 27 March and an M7.0 earthquake on 28 March (Table 1). Three other earthquakes with magnitude $>\mathrm{M} 6$ occurred before the principal earthquake struck on 2 April with an estimated magnitude of 7.9 [Wyss, 1988; Liang and Wyss, 1991; Wyss and Koyanagi, 1992]. The mainshock was followed by a 10-year long aftershock sequence [Wyss, 1988] and also by a period of near-continuous activity of Mauna Loa, mostly between the summit and the lower SWRZ [Lockwood and Lipman, 1987]. The eruptive volume during the 20 years following the M7.9 mainshock was about $1000 \times 10^{6} \mathrm{~m}^{3}$ (see Table 1). The reconstructed volume of the caldera subsidence during the early stages of the eruption was larger than the eruptive volume [cf. Lipman, 1995], indicating that not all the magma originating from the shallow magma chamber erupted at the surface but that it also intruded into the rift zones.

[44] The 1868 earthquake marked a dramatic change in lava chemistry, suggesting that the earthquake disrupted the Mauna Loa magma system [Tilling et al., 1987]. The vast majority of historic lavas were derived from a "long-lived, continuously replenished, well-mixed and homogenized, shallow magma reservoir" [Rhodes, 1995]. Following the great 1868 earthquake, however, a rare variety of lava flows erupted in the form of picrites [Rhodes, 1995; Tilling et al., 1987]. Moreover, for $2-3$ decades magmas were depleted in incompatible elements implying direct ascent from deeper levels without significant stagnation in the shallow magma chamber [Tilling et al., 1987]. Our work may provide an explanation for these relatively uncommon eruptive products and some insights into the processes during this sequence.

[45] The model calculations suggest that the earthquake unclamped most of the SWRZ and the summit region (Figure 7a). Indeed, during the 2 decades following the earthquake, eruptions occurred mainly along the SWRZ (Figure 8a, from $-45 \mathrm{~km}$ to $+12 \mathrm{~km}$; after Lockwood and Lipman [1987] and Barnard [1995] at the SWRZ at $1010 \mathrm{~m}$, $1740 \mathrm{~m}, 3960 \mathrm{~m}$, and at the NERZ at $3170 \mathrm{~m}$ ). This suggests that the subsequent dikes preferably propagated into part of the rift zone that was unclamped. The model calculations show that the rift zone was unclamped over its entire depth (from the decollement up to the surface, Figure 7a), which may also have facilitated the direct rise of magma from deeper levels and hence explains the ascent of picritic lavas. The earthquakes caused extension in and around the shallow magma chamber (Figure 8a), which is discussed in section 4.2.

\subsubsection{Kona Earthquakes: Two-Way Coupling During the 1949-1951 Activity}

[46] This sequence started with a summit eruption in January 1949. An M6.3 decollement earthquake occurred on 29 May 1950 in the Kona area [Klein and Wright, 2000]. Two days later on 1 June 1950, an eruption started at the summit caldera. This was followed by rapid fissure propagation into the SWRZ, where eruptive vents formed along a $20-\mathrm{km}$-long near-continuous line. This eruption was the most productive historic eruption, with $376 \times 10^{6} \mathrm{~m}^{3}$ of lava erupting during only 23 days. Lava flows reached the sea in less than 4 hours after the start of the eruption. The eruption was followed by another major earthquake in the Kona area with magnitude M6.9 on 21 August 1951.

[47] The 1949-1951 activity marked the end of a $>100$-year highly-active period of Mauna Loa [Lockwood and Lipman, 1987]. Before the 1949-1951 events, Mauna Loa had on average one eruption every 3.4 years [Lockwood and Lipman, 1987]. After the 1949-1951 events it had only two eruptions during 54 years (in 1975 and in 1984). The main volcanic activity on the Island of Hawaii switched from Mauna Loa to Kilauea, indicating a fundamental change of the magmatic plumbing and feeding systems.

[48] The stress transfer models help to understand some of the processes during this sequence. The 1950 eruption occurred from a dike that extended along the upper and central SWRZ from $-25 \mathrm{~km}$ to $+4 \mathrm{~km}$ (bracket in Figure $7 \mathrm{~b}$ ). This is consistent with the model calculations which show unclamping (Figure 6b) and suggests that stress changes due to the earthquake controlled the location and lateral extent of the dike. The earthquake also resulted in a decompression at the shallow magma chamber. The model calculations also show that SWRZ dike intrusions encourage decollement faulting in the Kona area (Figure 6c), suggesting that the 1950 dike encouraged, and possibly triggered the 1951 earthquake. The 1950-1951 sequence is an example of two-way volcano-earthquake interaction with an earthquake triggering an eruption and the dike associated with the eruption triggering another earthquake.

3.4.3. Effects of Kaoiki Earthquakes: The 1983-1984 Activity

[49] The 1983-1984 earthquake-eruption sequence started with summit doming in 1980 [Decker et al., 1983]. 
On 16 November 1983, a damaging magnitude M6.6 earthquake occurred in the Kaoiki area beneath Mauna Loa's southeast flank [Endo, 1985; Jackson et al., 1992]. An important piece of evidence for volcano-earthquake interaction is the measurement of fumarole activity in 1983. The measurements were done at one station at the caldera along an eruptive fissure from 1975 [see Lockwood et al., 1985, Figure 3]. A rise in temperature occurred on 18 November, only 2 days after the earthquake. A gradual increase in $\mathrm{H} 2$ using a $\mathrm{H} 2-\mathrm{O} 2$ fuel cell was detected on 21 November, just 5 days after the earthquake. This increase of fumarole activity led Lockwood et al. [1985] to propose that the earthquake enabled the upward migration of volcanic gases. Fluid mobilization was thus a direct response of the earthquake. A delayed response followed half a year later, when on 25 March 1984 an eruption started in the caldera. An eruptive fissure developed on the caldera floor and propagated into the NERZ. The principal vent developed $15 \mathrm{~km}$ away from the caldera [Lockwood et al., 1987]. The total eruptive volume was $\sim 220 \times 10^{6} \mathrm{~m}^{3}$ and the lava was uniform tholeiite.

[50] The model calculations show that Kaoiki decollement earthquakes cause unclamping of the NERZ (Figure 7c). This is the section of the rift zone into which the 1984 dike propagated; the surface extension of the dikes roughly agrees with the area of unclamping (Figure 6c). The precise pattern of stress changes associated with the 1983 earthquake is not known because the amount of vertical strike-slip faulting is not well constrained [Endo, 1985]. Assuming that the 1984 dike propagated into the unclamped rift zone area (i.e., the unclamped area and the actual dike length correlate), the inferred earthquake had mainly decollement slip component (Figure 7).

\section{Discussion}

[51] In a traditional view, deep magmatic processes control a volcano's behavior, the dike trends, lava production rate, and lava composition. Our study highlights the influence of shallow-level stress changes within or nearby the volcanic edifice. Understanding the stress field changes may help to reconstruct (and forecast) the location, magnitude, and type of both eruptive and seismic activity at active volcanoes.

[52] We studied the historic activity records at Mauna Loa volcano and found evidence for a relationship between large eruptions and earthquakes in time and space. To understand the co-occurrence of earthquakes and eruptions, we simulated the changes in the stress field for typical earthquakes and for dikes associated with typical eruptions. We considered earthquakes in the Hilea, Kona, and Kaoiki areas and dike intrusions into the SWRZ and NERZ. We showed that depending on the earthquake type and location, a specific part of the rift zone is unclamped. We showed that depending on the location of dike intrusion, specific parts of the active faults experience a Coulomb stress increase. Our models suggest that all earthquakes cause extension at the depth of the shallow magma chamber.

\subsection{Model Limitations}

[53] In our models we describe complex earthquakes as unit earthquakes with a magnitude of 6.2. This allowed us to compare the effect of earthquakes in the different seismic areas (Kona, Hilea, Kilauea), and to use the pattern of stress changes to understand eruptive events at Mauna Loa. A somewhat larger (or smaller) earthquake causes stronger (or weaker) stress changes but for linear elasticity the stress change pattern is comparable as long as the fault geometry does not change significantly.

[54] The geometries used for the dike models are based on observations from surface cracks and eruptive fissures, on geodetic measurements during the 1984 eruption, on estimates of eruption and intrusion volumes, and on structural measurements at eroded rift zones elsewhere on Hawaii. The associated stress changes, however, may be heterogeneous and locally much larger. When a dike intrusion reaches the surface and becomes an eruptive fissure, the overpressure is released and the dike may elastically close again to some extent, therefore stress changes may peak before an eruption. For simplicity, we herein assume uniform dike opening, which is associated with stress concentration at the dike margins.

[55] We do not consider any stress changes that may be caused by viscous relaxation of the magmatic system, lower crust, and/or uppermost mantle, which could though be important, especially for the large earthquakes such as the 1868 or the 1950 events.

[56] We considered stress changes associated with an expanding magma chamber during preeruptive inflation. We neglected coeruptive deflation in our model calculations because the shallow magma chamber under Mauna Loa appears to be continuously replenished so that deflation, in the long-term, is of minor importance [e.g., Johnson, 1995; Rhodes and Hart, 1995]. However, assuming that large dike intrusions and eruptions are fed from a shallow magma chamber, coeruptive deflation may be significant, the effects of which can be derived from the inflation models, because the associated stress changes have the same pattern and magnitude but opposite signs. Deflation therefore would discourage decollement earthquakes at Mauna Loa.

[57] Our model calculations cannot explain all eruptions or earthquakes that occurred in a sequence. For instance, the 1941 Kona earthquake was followed by a NERZ eruption, although our models would suggest eruption at the SWRZ. The 1868 Hilea earthquakes were followed by numerous eruptions at the summit, rather than by SWRZ eruptions only, and the 1914 summit eruption was followed by a Hilea earthquake. The 1915 Hilea earthquake was followed by the 1916 SWRZ eruption, which is in agreement with our model calculations. However, the 1916 SWRZ eruption should have encouraged mainly Hilea and Kona earthquakes but instead was followed by Hilea and Kaoiki earthquakes. Our model calculations imply that stress changes associated with dike intrusions strongly depend on the dike location so that above inconsistencies may be better understood with more realistic dike and fault parameters for each individual sequence.

\subsection{Mechanisms of Eruption Triggering}

[58] Although the body of evidence of co-occurring eruptions and earthquakes is growing, the mechanisms of eruption triggering are not understood. In general, a volcanic eruption is preceded by the buildup of pressure in magma bodies beneath the volcano and by the ascent of magma to shallower levels. When a system has evolved to a critical state it is very 
sensitive to small perturbations of the stress field [McLeod and Tait, 1999]. Small stress changes can trigger a sequence of events that result in an increase of the magma pressure and eventually lead to an eruption. Our model calculations for Mauna Loa suggest that all the preeruption earthquakes caused extension at levels of the shallow magma chamber and unclamping of the rift zones (Figures 7-8). Such a stress gradient may promote magma and fluid movement and mingling, cause vesiculation, or open structural pathways.

[59] Earthquake-induced dilatation may dissolve volatiles and/or facilitate the ascent of new magma and volatiles, which may increase both fluid pressure and buoyancy. Once the magma pressure exceeds the mechanical strength of the chamber walls a dike may propagate toward the surface and feed an eruption. Our results suggest that depending on the earthquake location (Kona, Hilea, Kaoiki area), extension at the rift zone occurs at specified areas only (NERZ, SWRZ). Existing fractures may be opened and connect and be used as a magma pathway [Kilburn, 2003].

\subsection{Influence of Earthquakes on Magma Composition and Eruption Volumes}

[60] The lavas of Mauna Loa are usually very homogeneous, even over a time span of over hundreds of years and fissure lengths of tens of kilometers. The majority of the lavas at Mauna Loa have compositions that are controlled by Olivine, with almost constant major element abundances at a given $\mathrm{MgO}$ content [e.g., Wright, 1971; Tilling et al., 1987; Rhodes, 1995]. Only five of the 38 historically documented eruptions had lavas with considerable compositional differences (1852, 1856, 1859, 1868, 1950), two of which had picritic lavas $(1852,1868)$ [Rhodes and Hart, 1995]. Their origin is probably a compositionally zoned source beneath the shallow magma reservoir and their eruption appears to be related to high eruption rates [Lockwood and Lipman, 1987; Rhodes, 1995]. As pointed out by Tilling et al. [1987] some of the significant changes in lava composition and eruption rate occurred during or following eruption-earthquake sequences, e.g., after the 1868 sequence or the 1949-1951 sequence. We propose that static stress changes associated with large flank earthquakes (e.g., 1868, 1949-1951) may be an important extrinsic method causing differences in both lava composition and eruption rate. A possible explanation is that extension and unclamping of the Mauna Loa magmatic system facilitates vertical and lateral magma migration and mixing of different magma zones and thus leads to the eruption of rare lava compositions and of higher eruption volumes. For comparison, on the Canary Islands it was suggested that lava composition and eruption rate may dramatically change after giant landslides, shown by picritic lavas that infilled a landslide scar on Tenerife [Walter and Schmincke, 2002]. Our study for Mauna Loa implies that already the occurrence of large earthquakes at unstable flanks (which impose much smaller stress changes than giant landslides) may be enough to disrupt a magma plumbing system and lead to an uncommon eruption.

\subsection{Mauna Loa Volcano-Earthquake Interaction Cycle}

[61] In this article we showed that volcanic activity causes a stress transfer which may encourage earthquakes.
Earthquakes, in turn, cause a stress transfer which may unclamp the rift zones and trigger dike intrusion and thus eruption. On the basis of the observations and modeling results we propose a volcano-earthquake interaction cycle for Mauna Loa (Figure 9).

[62] An earthquake at the basal decollement (Figure 9a) causes unclamping the rift zones and extension of the shallow magma chamber (Figure 9b). Eruption triggering may occur due to dike intrusion in the unclamped rift zones, vesicle growth, and buoyancy or pressure increase in the magma chamber, or by mingling of different magmas (Figure 9c). The eruption is associated with a dike intrusion into the rift zone (Figure 9d), compressing the adjacent flanks and changing the Coulomb failure stress at the decollement (Figure 9e). This may encourage another earthquake.

[63] The Mauna Loa volcano-earthquake cycle may initiate with an earthquake, with injection of new magma, with a dike intrusion, or with stress changes related to activity at a neighboring volcano.

\subsection{Other Processes of Interaction at Mauna Loa}

[64] This work considered only volcano-earthquake interaction. A more detailed analysis of eruption and earthquake occurrence at Mauna Loa requires consideration of all the sources of stress changes, including previous and distant events. For example, the possibility of another dike intrusion into the SWRZ does not only depend on previous Kona or Hilea earthquakes but also on previous intrusions into the NERZ as well as on active processes at Kilauea Volcano.

\subsubsection{Alternating Eruptions in the NERZ and the SWRZ}

[65] Dike intrusion into one segment of the rift zone may also affect the other rift zone segments. For instance, a dike intrusion into the SWRZ widens the rift zone further to the north and encourages dike intrusion into the NERZ. On the other hand, a dike intrusion into the NERZ widens the rift zone farther south, thus encouraging intrusions into the SWRZ. This has already been observed by Jaggar [1912], who noted that fissure locations roughly alternate between the NERZ and SWRZ, with summit eruptions between. For instance, eruptions during 1855-1868 occurred at the NERZ, then at the summit, and then at the SWRZ (Table 1). Eruptions during 1896-1914 occurred at the summit, NERZ, summit, SWRZ, and again at the summit. Eruptions during 1919-1940 occurred at the SWRZ, summit, NERZ, summit. The eruption record shows that alternating patterns were interrupted by eruption-earthquake sequences, for example in 1868, 1915-1916, or 1941-1942.

\subsubsection{Mauna Loa-Kilauea Interaction}

[66] The interconnectivity between Mauna Loa and Kilauea volcanoes has been discussed over the last 100 years [e.g., Jaggar, 1912; Klein, 1982; Miklius and Cervelli, 2003]. Petrologic data suggest that the volcanoes are independent. The lavas of Mauna Loa and Kilauea originate from parental lavas with distinct composition [Rhodes and Hart, 1995]. Large eruptions at Mauna Loa do not affect the lava production rate at Kilauea, also suggesting that the volcanoes are independent [Lockwood, 1995]. Recent geodetic data, however, propose the opposite. On 12 May 2002, Kilauea started a new eruptive period. At about the same 


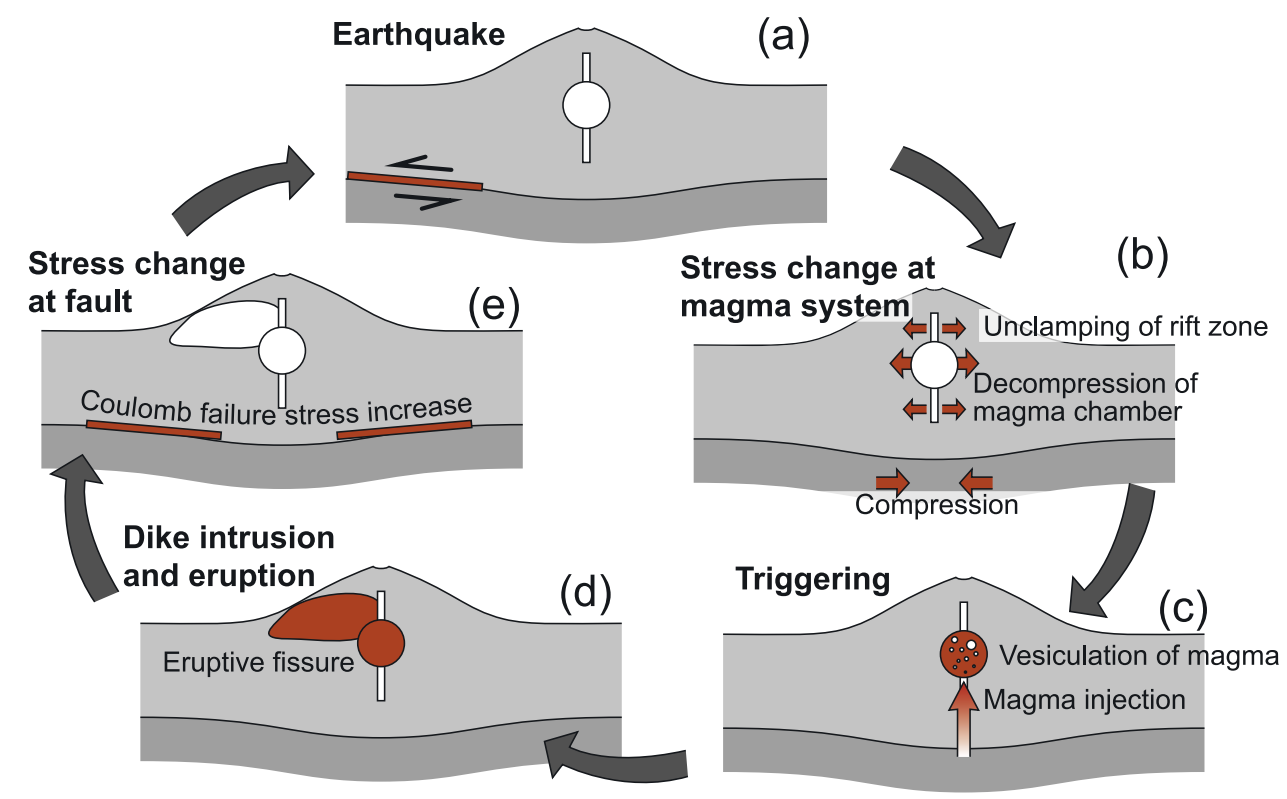

Figure 9. Cartoon of the volcano-earthquake interaction cycle for Mauna Loa.

time magma chamber inflation began at Mauna Loa, which led Miklius and Cervelli [2003] to propose that the magmatic systems are connected. Also, Klein [1982] suggested that when Mauna Loa was more active, Kilauea had fewer eruptions, and vice versa. Most dramatically, the 19491951 events were followed by a shift in volcanic activity from Mauna Loa to Kilauea as described above. Decollement slip may have modified not only the state of stress in the shallow Mauna Loa edifice but also within the surrounding.

\section{Conclusions}

[67] The main results of this study are as follows:

[68] 1. Eruptions and earthquakes and at Mauna Loa occur in sequence. Eruptions at the SWRZ are coupled with earthquakes in the Kona and Hilea areas, and eruptions at the NERZ are coupled with earthquakes in the Kaoiki area.

[69] 2. Static stress changes can explain most of the observed temporal and spatial coupling between earthquakes and eruptions.

[70] 3. Earthquakes cause decompression of the shallow magma chamber.

[71] 4. Earthquake-induced clamping and unclamping of the rift zones controls dike propagation such as direction and dimension of fissures and the location of eruptive vents (interconnectivity in time and space), and may influence eruption volume, lava composition, and hydrothermal activity.

[72] Acknowledgments. We thank S. Rowland, G. King, E. Endo, S. Martel, and P. Lundgren for discussions at early stages of this work. The program Poly3d was provided by D. Pollard, Stanford University. The paper benefited from constructive reviews by D. Hill, J. Kauahikaua, C. Troise, and Y. Fukushima. Funding was provided by an Emmy Noether Junior Research Program of the German Research Council (DFG \#WA $1642 / 1-4)$ to TRW and by the NASA Adro-2 program to FA.

\section{References}

Amelung, F., A. Miklius, and T. R. Walter (2003), The magma reservoir of Mauna Loa volcano, Hawaii: Constraints from InSAR geodetic measurements, Eos Trans. AGU, 84(46), Fall Meet. Suppl., Abstract V11B-04.

Ando, M. (1979), The Hawaii earthquake of November 29, 1975: Low dip angle faulting due to forceful injection of magma, J. Geophys. Res., 84, $7616-7626$.

Barnard, W. M. (1995), Mauna Loa volcano: historical eruptions, exploration, and observation (1779-1910), in Mauna Loa Revealed: Structure, Composition, History, and Hazards, Geophys. Monogr. Ser., vol. 92, edited by J. M. Rhodes and J. P. Lockwood, pp. 1-21, AGU, Washington, D. C.

Bautista, B. C., L. P. Bautista, E. S. Barcelona, R. S. Punongbayan, E. P. Laguerta, A. R. Rasdas, G. Ambubuyog, E. Q. Amin, and R. S. Stein (1996), Relationship of regional and local structures to Mount Pinatubo activity, in The 1991-1992 Eruptions of Mount Pinatubo, Philippines, edited by C. G. Newhall and R. S. Punongbayan, pp. 351-370, Univ. of Wash. Press, Seattle.

Beeler, N. M., R. W. Simpson, S. H. Hickman, and D. A. Lockner (2000), Pore fluid pressure, apparent friction; and Coulomb failure, J. Geophys. Res., 105, 25,533-25,542.

Beisser, M., D. Gillard, and M. Wyss (1994), Inversion for source parameters from sparse data sets: Test of the method and application to the 1951 (M6.9) Kona, Hawaii, earthquake, J. Geophys. Res., 99, 19,66119,678 .

Borgia, A., P. T. Delaney, and R. P. Denlinger (2000), Spreading volcanoes, Annu. Rev. Earth Planet. Sci., 28, 539-570.

Bryan, C. J., and C. E. Johnson (1991), Block tectonics of the island of Hawaii from a focal mechanism analysis of basal slip, Bull. Seismol. Soc. Am., 81, 491-507.

Cayol, V., and F. H. Cornet (1998), Effect of topography on the interpretation of the deformation field of prominent volcanoes: Application to Etna, Geophys. Res. Lett., 25, 1979-1982.

Cayol, V., J. Dieterich, A. Okamura, and A. Miklius (2000), High magma storage rates before the 1983 eruption of Kilauea, Hawaii, Science, 288, $2343-2346$

Comninou, M. A., and J. Dundurs (1975), The angular dislocation in a halfspace, J. Elasticity, 5, 203-216.

Decker, R. W. (1987), Dynamics of Hawaiian volcanoes: An overview, U.S. Geol. Surv. Prof. Pap., 1350, 997-1018.

Decker, R. W., R. Y. Koyanagi, J. J. Dvorak, J. P. Lockwood, A. T. Okamura, K. M. Yamashita, and W. R. Tanigawa (1983), Seismicity and surface deformation of Mauna Loa Volcano, Hawaii, Eos Trans. $A G U, 64(37), 545-547$.

Delaney, P. T., R. P. Denlinger, M. Lisowski, A. Miklius, P. G. Okubo, A. T. Okamura, and M. K. Sako (1998), Volcanic spreading at Kilauea, 19761996, J. Geophys. Res., 103, 18,003-18,024.

Dieterich, J. H. (1988), Growth and persistence of Hawaiian volcanic rift zones, J. Geophys. Res., 93, 4258-4270.

Dieterich, J. H., V. Cayol, and P. Okubo (2003), Stress changes before and during the Pu'u 'O'o-Kupaianaha eruption, U.S. Geol. Surv. Prof. Pap., 1676, 187-201. 
Endo, E. T. (1985), Seismotectonic framework for the southeast flank of Mauna Loa, Hawaii, Ph.D. thesis, 349 pp., Univ. of Wash., Seattle, Wash.

Fiske, R. F., and E. D. Jackson (1972), Orientation and growth of Hawaiian volcanic rifts: the effect of regional structure and gravitational stresses, Proc. R. Soc. London, 329, 299-326.

Gillard, D., M. Wyss, and J. S. Nakata (1992), A seismotectonic model for western Hawaii based on stress tensor inversion from fault plane solutions, J. Geophys. Res., 97, 6629-6641.

Got, J. L., and P. Okubo (2003), New insights into Kilauea's volcano dynamics brought by large-scale relative relocation of microearthquakes, J. Geophys. Res., 108(B7), 2337, doi:10.1029/2002JB002060.

Hill, D. P., and J. J. Zucca (1987), Geophysical constraints on the structure of Kilauea and Mauna Loa volcanoes and some implications for seismomagmatic processes, U.S. Geol. Surv. Prof. Pap., 1350, 903-917.

Hill, D. P., F. Pollitz, and C. Newhall (2002), Earthquake-volcano interactions, Phys. Today, 55(11), 41-47.

Jackson, M. D., E. T. Endo, P. T. Delaney, T. Arnadottir, and A. M. Rubin (1992), Ground ruptures of the 1974 and 1983 Kaoiki earthquakes, Mauna-Loa volcano, Hawaii, J. Geophys. Res., 97, 8775-8796.

Jaggar, T. A. (1912), Report of the Hawaiian Volcano Observatory of the Massachusetts Institute of Technology and the Hawaiian Volcano Research Association: January-March 1912, in The Early Serial publications of the Hawaiian Volcano Observatory, vol. 1, edited by D. Bevens, T. J. Takahashi, and T. L. Wright, pp. 1-73, Hawaii Natural History Assoc., Hawaii National Park, Hawaii.

Johnson, D. J. (1995), Gravity changes on Mauna Loa volcano, in Mauna Loa Revealed: Structure, Composition, History, and Hazards, Geophys. Monogr. Ser., vol. 92, edited by J. M. Rhodes and J. P. Lockwood, pp 127-143, AGU, Washington, D. C

Kauahikaua, J., T. G. Hildenbrand, and M. Webring (2000), Deep magmatic structures of Hawaiian volcanoes imaged by three-dimensional gravity models, Geology, 28(10), 883-886.

Kilburn, C. R. J. (2003), Multiscale fracturing as a key to forecasting volcanic eruptions, J. Volcanol. Geotherm. Res., 125, 271-289.

King, G. C. P., R. S. Stein, and J. Lin (1994), Static stress changes and the triggering of earthquakes, Bull. Seismol. Soc. Am., 84, 935-953.

Klein, F. W. (1982), Patterns of historical eruptions at Hawaiian Volcanoes, Hawaii, Radiocarbon, 21, 306-320.

Klein, F. W., and T. L. Wright (2000), Catalog of Hawaiian earthquakes, 1823-1959, U.S. Geol. Surv. Prof. Pap., 1623, 90 pp.

Liang, B., and M. Wyss (1991), Estimates of orientations of stress and strain tensors based on fault-plane solutions in the epicentral area of the great Hawaiian earthquake of 1868, Bull. Seismol. Soc. Am., 81 $2320-2334$

Linde, A. T., and I. S. Sacks (1998), Triggering of volcanic eruptions, Nature, 395,888

Lipman, P. W. (1995), Declining growth of Mauna Loa during the last 100,000 years: Rates of lava accumulation vs. gravitational subsidence, in Mauna Loa Revealed: Structure, Composition, History, and Hazards, Geophys. Monogr. Ser., vol. 92, edited by J. M. Rhodes and J. P. Lockwood, pp. 45-80, AGU, Washington, D. C.

Lipman, P. W., J. P. Lockwood, R. T. Okamura, D. A. Swanson, and K. M. Yamashita (1985), Ground deformation associated with the 1975 magnitude-7.2 earthquake and resulting changes in activity of Kilauea Volcano, Hawaii, U.S. Geol. Surv. Prof. Pap., 1276, 45.

Lockwood, J. P. (1995), Mauna Loa eruptive history: The preliminary radiocarbon record, Hawaii, in Mauna Loa Revealed: Structure, Composition, History, and Hazards, Geophys. Monogr. Ser., vol. 92, edited by J. M. Rhodes and J. P. Lockwood, pp. 81-94, AGU, Washington, D. C.

Lockwood, J. P., and P. W. Lipman (1987), Holocene eruptive history of Mauna Loa Volcano, Hawaii, U.S. Geol. Surv. Prof. Pap., 1350, 509535

Lockwood, J. P., N. G. Banks, T. T. English, L. P. Greenland, D. B Jackson, D. J. Johnson, R. Y. Koyanagi, K. A. McGee, A. T. Okamura, and J. M. Rhodes (1985), The 1984 eruption of Mauna Loa Volcano, Hawaii, Eos Trans. AGU, 66(16), 169-171.

Lockwood, J. P., J. J. Dvorak, T. T. English, R. Y. Koyanagi, A. T. Okamura, M. L. Summers, and W. R. Tanigawa (1987), Mauna Loa 1974-1984: A decade of intrusive and extrusive activity, U.S. Geol. Surv. Prof. Pap., 1350, 537-570.

Martel, S. J., and J. Muller (2000), A two-dimensional boundary element method for calculating elastic gravitational stresses in slopes, Pure Appl. Geophys., 157, 989-1007.

Marzocchi, W., E. Casarotti, and A. Piersanti (2002), Modeling the stress variations induced by large earthquakes on the largest volcanic eruptions of the 20th century, J. Geophys. Res., 107(B11), 2320, doi:10.1029/ 2001JB001391.

McLeod, P., and S. R. Tait (1999), The growth of dykes from magma chambers, J. Volcanol. Geotherm. Res., 92, 231-246.
Miklius, A., and P. Cervelli (2003), Interaction between Kilauea and Mauna Loa, Nature, 421, 229.

Miklius, A., M. Lisowski, P. T. Delaney, R. P. Denlinger, J. J. Dvorak, A. T. Okamura, and M. K. Sako (1995), Recent inflation and flank movement of Mauna Loa volcano, in Mauna Loa Revealed: Structure, Composition, History, and Hazards, Geophys. Monogr. Ser, vol. 92, edited by J. M. Rhodes and J. P. Lockwood, pp. 199-205, AGU, Washington, D. C.

Mogi, K. (1958), Relations between the eruptions of various volcanoes and the deformation of the ground surfaces around them, Bull. Earthquake Res. Inst. Univ. Tokyo, 36, 99-134.

Morgan, J. K., G. F. Moore, and D. A. Clague (2003), Slope failure and volcanic spreading along the submarine south flank of Kilauea volcano, HI, J. Geophys. Res., 108(B9), 2415, doi:10.1029/2003JB002411.

Munson, C. G., C. H. Thurber, Y. Li, and P. G. Okubo (1995), Crustal shear wave anisotropy in southern Hawaii: Spatial and temporal analysis, J. Geophys. Res., 100(B10), 20,367-20,377.

Nakamura, H. (1975), Volcano structure and possible mechanical correlation between volcanic eruptions and earthquakes, Bull. Volcanol. Soc. Jpn., 2(20), 229-240.

Nakamura, K. (1980), Why do long rift zones develop in Hawaiian volcanoes: A possible role of thick oceanic sediments, Bull. Geol. Soc. Jpn., $25,255-269$.

Nostro, C., R. S. Stein, M. Cocco, M. E. Belardinelli, and W. Marzocchi (1998), Two-way coupling between Vesuvius eruptions and southern Apennine earthquakes (Italy) by elastic stress transfer, J. Geophys. Res., 103, 24,487-24,504.

Okubo, P. (1995), A seismological framework for Mauna Loa Volcano, in Mauna Loa Revealed: Structure, Composition, History, and Hazards, Geophys. Monogr. Ser., vol. 92, edited by J. M. Rhodes and J. P. Lockwood, pp. 187-198, AGU, Washington, D. C.

Okubo, P., H. M. Benz, and B. A. Chouet (1997), Imaging the crustal magma sources beneath Mauna Loa and Kilauea, Hawaii, Geology, 25(10), 867-870

Rhodes, J. M. (1995), The 1852 and 1868 Mauna Loa picrite eruptions: clues to parental magma compositions and the magmatic plumbing system, in Mauna Loa Revealed: Structure, Composition, History, and Hazards, Geophys. Monogr. Ser., vol. 92, edited by J. M. Rhodes and J. P. Lockwood, pp. 241-262, AGU, Washington, D. C.

Rhodes, J. M., and S. R. Hart (1995), Episodic trace element and isotopic variations in historical Mauna Loa lavas: Implications for magma and plume dynamics, in Mauna Loa Revealed: Structure, Composition, History, and Hazards, Geophys. Monogr. Ser, vol. 92, edited by J. M. Rhodes and J. P. Lockwood, pp. 263-288, AGU, Washington, D. C.

Rockstroh, E. (2002), Earthquake in Guatemala, Nature, 66, 150.

Stein, R. S. (1999), The role of stress transfer in earthquake occurrence, Nature, 402, 605-609.

Swanson, D. A., W. A. Duffield, and R. S. Fiske (1976), Displacement of the south flank of Kilauea volcano: The result of forceful intrusion of magma into the rift zones, U.S. Geol. Surv. Prof. Pap., 963, 1-39.

Thatcher, W., and J. C. Savage (1982), Triggering of large earthquakes by magma-chamber inflation, Izu Peninsula, Japan, Geology, 10, 637640.

Thomas, A. L. (1993), Poly3D: A three-dimensional, polygonal element, displacement discontinuity boundary element computer program with applications to fractures, faults, and cavities in the Earth's crust, M.S thesis, Stanford Univ., Stanford, Calif.

Tilling, R. I., J. M. Rhodes, J. W. Sparks, J. P. Lockwood, and P. W. Lipman (1987), Disruption of the Mauna Loa magma system by the 1868 Hawaiian earthquake: Geochemical evidence, Science, 235, $196-$ 199

Troise, C. (2001), Stress changes associated with volcanic sources: Constraints on Kilauea rift dynamics, J. Volcanol. Geotherm. Res., 109, $191-$ 203

Trusdell, F. A. (1995), Lava flow hazards and risk assessment on Mauna Loa volcano, Hawaii, in Mauna Loa Revealed: Structure, Composition History, and Hazards, Geophys. Monogr. Ser, vol. 92, edited by J. M. Rhodes and J. P. Lockwood, pp. 327-336, AGU, Washington, D. C.

Walker, G. P. L. (1987), The dike complex of Koolau Volcano, Ohahu: Internal structure of a Hawaiian rift zone, U.S. Geol. Surv. Prof. Pap., $1350,961-993$

Walter, T. R., and F. Amelung (2004), Influence of volcanic activity at Mauna Loa, Hawaii, on earthquake occurrence in the Kaoiki Seismic Zone, Geophys. Res. Lett., 31, L07622, doi:10.1029/2003GL019131.

Walter, T. R., and H.-U. Schmincke (2002), Rifting, recurrent landsliding and Miocene structural reorganization on NW-Tenerife (Canary Islands), Int. J. Earth Sci., 91, 615-628

Walter, T. R., V. Acocella, M. Neri, and F. Amelung (2005), Feedback processes between magmatic events and flank movement at Mount Etna (Italy) during the 2002-2003 eruption, J. Geophys. Res., 110, B10205, doi:10.1029/2005JB003688. 
Wolfe, C. J., P. G. Okubo, G. Ekstroem, M. Nettles, and P. M. Shearer (2004), Characteristics of deep (>13 km) Hawaiian earthquakes and Hawaiian earthquakes west of $155.55 \mathrm{~W}$, Geochem. Geophys. Geosyst., 5, Q04006, doi:10.1029/2003GC000618.

Wolfe, E. W., and J. Morris (1996), Geologic map of the island of Hawaii, U.S. Geol. Surv. Misc. Invest. Ser. Map, I-2524-A.

Wright, T. L. (1971), Chemistry of Kilauea and Mauna Loa lavas in space and time, U.S. Geol. Surv. Prof. Pap., 735, 1-49.

Wyss, M. (1986), Regular intervals between Hawaiian earthquakes: Implications for predicting the next event, Science, 234, 726-728.

Wyss, M. (1988), A proposed source model for the great Kau, Hawaii, earthquake of 1868, Bull. Seismol. Soc. Am., 78, 1450-1462.

Wyss, M., and R. Y. Koyanagi (1992), Isoseismal maps, macroseismic epicenters and estimated magnitudes of historic earthquakes in the Hawaiian Islands, U.S. Geol. Surv. Bull., 2006, 93 pp.

Wyss, M., B. Liang, W. R. Tanigawa, and X. Wu (1992), Comparison of orientations of stress and strain tensors based on fault plane solutions in Kaoiki, Hawaii, J. Geophys. Res., 97, 4769-4790.

Wyss, M., F. Klein, K. Nagamine, and S. Wiemer (2001), Evidence for magma at intermediate crustal depth below Kilauea's East Rift, Hawaii, based on anomalously high b-values, J. Volcanol. Geotherm. Res., 106, $23-37$

Yang, X. M., P. M. Davis, and J. H. Dieterich (1988), Deformation from inflation of a dipping finite prolate spheroid in an elastic half-space as a model for volcanic stressing, J. Geophys. Res., 93, 4249-4257.

Yun, S., F. Amelung, A. Miklius, T. Walter, and P. Segall (2005), Magma chamber geometry at Mauna Loa volcano from InSAR and GPS 2002 2004, Eos Trans. AGU, 86(52), Fall Meet. Suppl., Abstract G52A-07.

Zobin, V. M., and V. I. Levina (1998), Rupture history of the January 1, 1996, Ms 6.6 volcanic earthquake preceding the simultaneous eruption of Karymsky and Akademia Nauk volcanoes in Kamchatka, Russia, J. Geophys. Res., 103, 18,315-18,324.

F. Amelung, Division of Marine Geology and Geophysics, Rosenstiel School of Marine and Atmospheric Sciences, University of Miami, 4600 Rickenbacker Causeway, Miami, FL 33149, USA.

T. R. Walter, Section 2.1, GeoForschungsZentrum Potsdam, Telegrafenberg, D-14473 Potsdam, Germany. (twalter@gfz-potsdam.de) 